\title{
Evaluation of ocean chlorophyll-a remote sensing algorithms using in situ fluorescence data in Southern Brazilian Coastal Waters
}

\author{
Gabriel Serrato de Mendonça Silva ${ }^{1, *}$, Carlos Alberto Eiras Garcia' ${ }^{\circledR}$
}

\begin{abstract}
${ }^{1}$ Universidade Federal de Santa Catarina - UFSC (Rua Eng. Agronômico Andrey Cristian Ferreira, Blocos Modulados do Centro de Ciências Físicas e Matemáticas - CFM, Corredor B, Sala B-14, 88040-900 - Florianópolis - SC - Brazil)

* Corresponding author: gabrielsmsilva@gmail.com
\end{abstract}

\section{Abstract}

A performance evaluation of ocean color chlorophyll- $a$ algorithms was conducted based on the in situ fluorescence chlorophyll concentration $\left(F_{c h l}\right)$ measured by a sensor on the buoy SiMCosta-SC01 in coastal waters of South Brazil. The operational algorithms are used in MODIS and VIIRS sensors to derive satellite chlorophyll concentration $\left(C_{\text {sal }}\right)$. $F_{c h l}$ values were successfully corrected for nonphotochemical quenching (NPQ) by an interpolation of sunrise and sunset daily measurements. A laboratory-derived calibration coefficient was applied to convert the unquenching $F_{c h l}$ values into chlorophyll concentration $\left(C_{f u}\right)$. Overall, linear regression analysis between $C_{f l u}$ and $C_{\text {sat }}$ for both sensors showed good results, with the coefficient of determination $\left(R^{2}\right)$ varying between 0.88 and 0.96 , slopes between 0.92 and 1.02 and intercepts between -0.17 and 0.13 . The MODIS algorithm $\left(R^{2}=0.96\right.$, slope $=1.02, R M S E=0.16 \mathrm{mg} \mathrm{m}^{-3}, \mathrm{BIAS}=0.16 \mathrm{mg} \mathrm{m}^{-3}$, for $\mathrm{N}=222$ and time interval $\pm 1 \mathrm{~h}$ ) presented slightly better performance than VIIRS $\left(\mathrm{R}^{2}=0.92\right.$, slope $=0.96, \mathrm{RMSE}=0.25$ $\mathrm{mg} \mathrm{m}^{-3}, \mathrm{BIAS}=-0.25 \mathrm{mg} \mathrm{m}^{-3}$, for $\mathrm{N}=284$ and time interval $\pm 1 \mathrm{~h}$ ). These results represent the most comprehensive satellite data analysis for this region, suggesting that the approach may be applicable to other SiMCosta buoys.

Descriptors: Ocean color, MODIS, VIIRS, Southern Brazilian Coastal Waters, in situ fluorescence chlorophyll-a, moored measurements.

\section{INTRODUCTION}

Technological advances in space missions in recent decades have allowed the development of sensors such as the Coastal Zone Color Scanner (CZCS), Moderate Resolution Imaging Spectroradiometer (MODIS) (Salomonson et al., 1989), Ocean Color and Temperature Scanner (OCTS) (Iwasaki et al., 1992),

Submitted: 09-October-2020

Approved: 15-February-2021

Editor: Rubens M. Lopes

(c) 2021 The authors. This is an open access article distributed under the terms of the Creative Commons license.
Sea-viewing Wide Field-of-view Sensor (SeaWiFS) (Hooker et al., 1992), Medium Resolution Imaging Spectrometer (MERIS) (Rast and Bezy, 1999) and, more recently, Visible Infrared Imager / Radiometer Suite (VIIRS) (Welsch et al., 2001). Such development permitted researchers to conduct pioneering ocean color studies with high spatial and temporal resolutions. Nowadays, different research fields of oceanography use ocean color satellite imagery, with studies that include the evaluation of eutrophication processes (e.g. Peñaflor et al., 2007; Klemas, 2011; Banks et al., 2012), spatiotemporal distribution of Chl- $a$ (e.g. Gower and King, 2007; Garcia and Garcia, 
2008; Henson et al., 2009; Park et al., 2010; Song et al., 2010), biogeochemical cycles (e.g. Focardi, et al., 2009; Chang and Xuan, 2011) and marine ecosystem responses to climate change and to anthropogenic impacts (Shi and Wang, 2007; Zhao et al., 2008; Kahru et al., 2010; Henson et al., 2010, Cloern et al., 2014).

The development of algorithms and models in the last forty years (see Blondeau-Patissier et al., 2014) was guided by a demand to decrease the uncertainty in estimating $\mathrm{Chl}-a$ concentration using satellite information. Among the developed algorithms, we can highlight the empirical algorithms that are obtained through the relationship between optical measurements and the concentrations of constituents sampled in situ, and the semi-analytical algorithms, developed through theoretical mathematical formulations with statistical adjustments (IOCCG, 2000).

The spectral reflectance of sea water in the visible wavelength depends on its optical constituents: (i) phytoplankton (suspended algae) and suspended particles related to algal activity, (ii) non-algal suspended solids, and (iii) colored dissolved natural organic matter (CDOM). In open ocean, (i) phytoplankton dominates, whereas in coastal and estuarine regions we normally have a predominance of (ii) and (iii). The spectral reflectance can be approximated (first order) to the ratio of spectral backscattering and absorption. Algae appears green because their pigments absorb blue and red photons, although have minimal absorbance in the green range. The resulting reflectance peak is around $550 \mathrm{~nm}$ (green). However, non-organic suspended matter also contributes to backscattering in the green range. CDOM absorbs strongly in the blue range, decreasing its absorption with increasing wavelength. Since absorbance by CDOM and scattering by particles can affect the Rrs(blue)/Rrs(green) ratio, the retrieval of chlorophyll concentration in coastal waters using standard algorithms present certain uncertainties due to the presence of these non-algal constituents.

Empirical (Garcia et al, 2005, Giannini et al. 2013) and semi-analytical (Garcia et al., 2006) algorithms have been evaluated for the region influenced by the La Plata river discharge. The overall results demonstrated the need for appropriate calibration of semi-analytical algorithms from measurements of the inherent optical properties. They also showed the need for additional in situ data of radiometric and chlorophyll concentration to improve the accuracy of empirical algorithms. Ciotti et al. (2010) evaluated the seasonal and meridional variability of surface Chl- $a$ concentration for the entire Brazilian continental shelf, concluding that the use of remote sensing for time series construction makes it possible to estimate phytoplankton biomass and to identify long-term trends in primary productivity off the Brazilian coast. Specifically, for the coastal region of Santa Catarina state, few studies have related $\mathrm{Chl}-a$ concentrations from in situ data and satellite estimates. An attempt was made during the Environmental Monitoring Project of the Arvoredo and Surrounding Marine Biological Reserve (MAARE, 2017). For this, the authors used time windows (time difference between data collection and satellite passage) of approximately 24 hours to increase the number of paired samples. They found a relatively low relationship $\left(R^{2}\right.$ $=0.36$ ) and concluded that there was a need for more refined analyses with a larger amount of data under different oceanographic conditions in the region.

In recent years, the Brazilian Coastal Monitoring System (SiMCosta) has been implemented along the Brazilian coast. SiMCosta uses floating and/or fixed platforms, equipped with instruments and sensors, with autonomous operation, and the ability to regularly collect oceanographic and meteorological variables (http://simcosta.furg.br/artigos/project). In February 2017, a SiMCosta meteocean buoy, named SiMCosta-SC01, was deployed in the Rebio Arvoredo. Among the oceanographic variables sampled by the SiMCosta-SC01 buoy, we highlight the sea surface temperature, salinity, dissolved oxygen, turbidity, and $\mathrm{Chl}-a$ stimulated fluorescence (calibrated in Chl- $a$ concentration units). This set of information acquired simultaneously allows for an integrated analysis through statistical methods to understand which factors are responsible for $\mathrm{Chl}-a$ variability in the region and, consecutively, to understand the ecological processes related to primary productivity in the region.

It is important to highlight the social and economic significance of studies related to the distribution patterns of phytoplankton biomass and its associated processes in the Santa Catarina coast region, as articulated by Rörig et al. (2018). The authors identified that the structure of the phytoplankton communities, and their distribution, are caused by the influence of river discharge, the phenomenon of 
coastal resurgence, and seasonal variation in the distribution of water mass in the region. The authors also pointed out that the economic activities of fishing and mariculture, traditional in the region, are directly influenced by phytoplankton blooms, producing positive and negative effects (toxic algae). Hence, this study may also contribute with data to support wider socio-economic research in the region.

Several authors highlighted the relevance of acquiring sea-truth data simultaneously to the passage of the orbital sensors (e.g., Werdell and Bailey, 2005; Ciotti et al., 2010; IOCCG, 2013; Blondeau-Patissier, 2014). Therefore, due to the availability of in situ fluorescence data collected by buoy SiMCosta-SC01, this study evaluates the existing operational $\mathrm{Chl}-a$ concentration algorithm for MODIS-Aqua, MODIS-Terra, VIIRS-NOAA20 and VIIRS-SNPP by comparing satellite Chl- $a$ estimates with in situ chlorophyll concentration. The metrics used for those comparisons followed the most recent recommendations published on Seegers et al. (2018) and Pereira et al. (2018). In addition, an effort was made to infer the consequences of using pixels both contaminated and not contaminated by straylight.

\section{METHODS}

\section{Study SITE}

The central coast of Santa Catarina has unique characteristics that demonstrate a need for research and technical-scientific development that foster sustainable management and development in its coastal and marine environments. Located in the internal and extreme south portion of the Southeast Brazilian Continental Platform (PCSE) - limited to the north at latitude $23^{\circ} \mathrm{S}$ close to the city of Cabo Frio in Rio de Janeiro, and to the south at latitude $28.5^{\circ} \mathrm{S}$ close to Cabo de Santa Marta Grande in the state of Santa Catarina (Castro Filho and Miranda, 1998) - the central coast of the state of Santa Catarina has attributes of economic relevance, such as comprising Brazil's largest production of oysters, scallops and mussels. Due to its environmental relevance, the Arvoredo Marine Biological Reserve (Rebio Arvoredo) was created in 1990 for the integral protection and conservation of coastal ecosystems, their islands and islets, as well as their waters, the continental shelf and its associated resources (BRAZIL, 1990). Rebio Arvoredo covers an area of $17,104.60$ hectares, approximately $11 \mathrm{~km}$ north of the Island of Santa Catarina, and delimited between the coordinates $27.15^{\circ} \mathrm{S}, 48.31^{\circ} \mathrm{W}$ and $27.30^{\circ} \mathrm{S}, 48.42^{\circ} \mathrm{W}$.

The central coast of the state of Santa Catarina is directly influenced by oceanic water and continental outflows. Through the thermohaline indices of oceanic water bodies present in the PCSE, Möller et al., (2008) identified the Tropical Water (TW) as hot and saline water $\left(T \geq 18.5^{\circ} \mathrm{C}, \mathrm{S} \geq 36\right)$, the South Atlantic Central Water (SACW), cold and less saline $\left(\mathrm{T} \leq 18.5^{\circ} \mathrm{C}\right.$, $S \geq 35.3$ ), the Subtropical Shelf Water (STSW), and the Plate River Plume Water (PPW), with low temperature and low salinity $\left(\mathrm{T}>10^{\circ} \mathrm{C}, \mathrm{S} \leq 33.5\right)$. Seasonally, due to the different wind patterns in the region, these water bodies undergo mixtures and acquire peculiar characteristics. Especially during the summer and spring months, TW undergoes periodic mixtures with SACW, forming the summer STSW ( $\mathrm{T}>18.5^{\circ} \mathrm{C}, 35.3<\mathrm{S}<36$ ) (Bordin et at. 2019). The oceanographic phenomenon of coastal upwelling in the region occurs due to the action of the predominant N-NE winds causing the SACW intrusion on the platform (Campos et al., 2013). During the winter months, with the predominance of S-SE winds associated with the passage of cold fronts, the displacement of the PPW to the north occurs, and its mixture with the TW result in the winter STSW (T> $14{ }^{\circ} \mathrm{C}, 33.5 \leq \mathrm{S}<35.3$ ) (Bordin et al., 2019).

Regarding the supply of continental water, influences on the coastal zone are caused by the discharge of the Tijucas River, through the channel of the North Bay of Santa Catarina Island (Schettini et al., 1996) and the Itajaí-Açu River - the largest river in the region, to be highlighted - whose plume generally moves in the N-NE direction (Carvalho et al., 2010). Campos et al. (2013) point out that the influence of the Itajaí-Açu River over Rebio Arvoredo may occur in sporadic situations in the Rebio region.

The materials flowing from these river systems are extremely important in the distribution of physical, chemical and biological properties in the waters of Rebio Arvoredo (Paquette et al., 2016). As it contains nutrients associated with urban effluents and local agriculture, the supply of continental material can sporadically cause significant changes in temperature, salinity, turbidity, concentrations of $\mathrm{Chl}-a$, 
particulate and dissolved organic and inorganic material and, consequently, in the overall properties of the coastal waters.

Following the standard climatological classification of Köppen and Geiger (1954), the coast of Santa Catarina has humid subtropical mesothermal climate with hot summer (Cfa). The region has annual average temperatures between $19{ }^{\circ} \mathrm{C}$ and $20^{\circ} \mathrm{C}$, with average annual minimums between $15^{\circ} \mathrm{C}$ and $16^{\circ} \mathrm{C}$ and average annual maximum between $25^{\circ} \mathrm{C}$ and $26^{\circ} \mathrm{C}$. The annual relative humidity varies between $82 \%$ and $86 \%$, and the total annual precipitation between 30 and $40 \mathrm{~mm}$ (Pandolfo et al., 2002). It should be noted that the region may have significant interannual variations influenced by climatic fluctuations, such as the El Niño and La Niña phenomena (Grimm, 2009b).

\section{IN SITU DATA COLLECTION}

The moored monitoring buoy system SiMCostaSC01 was deployed on 2017 February 22 inside Rebio Arvoredo, over the central coast of Santa Catarina state, at $27^{\circ} 16.46^{\prime} \mathrm{S}$ and $48^{\circ} 25.26^{\prime} \mathrm{W}$ (Figure 1). This buoy SC01 has an optical WET Labs WQM (Water Quality Monitor) sensor fixed at approximately 1-meter depth. The above WQM is part of four optical devices that was acquired by SiMCosta to be deployed along the
Brazilian coast. All four WQM were calibrated at factory prior to deployment, and one of the WET Labs WQM, deployed in the São Sebastião channel (SP, Brazil), was used as calibration. The WQM sensor has an integrated copper anti-fouling bio-wiper system that cleans the optical lens before any measurement can be taken to prevent fouling caused by natural algal biofilm. Full maintenance of the sensor occurs every three months by SiMCosta's team. During the maintenance stage, the WQM data was downloaded directly from the sensor to ensure that all information automatically sent by the buoy's telemetry system was equal to the sensors' backup. The in situ dataset was composed by means of 20 second acquisitions every hour of chlorophyll- $a$ from fluorescence $\left(F_{\text {chl-raw }}\right)$, temperature and salinity, between 2017 February 22 and 2019 November 17, and obtained from http://simcosta.furg.br/.

Complementary hourly data of solar radiation (in $\mathrm{KJ} \mathrm{m}^{2}$ ) from a meteorological automated station located in Florianópolis city (see Figure 1 ), at $27^{\circ} 36^{\prime}$ $\mathrm{S}$ and $48^{\circ} 36^{\prime} \mathrm{W}$, was obtained through a request form at the National Meteorology Institute (INMET). These data were firstly converted to photosynthetically active radiation (PAR) by a factor of 0.47 and then used for correcting non-photochemical quenching effect on in situ Chl- $a$ fluorescence data.
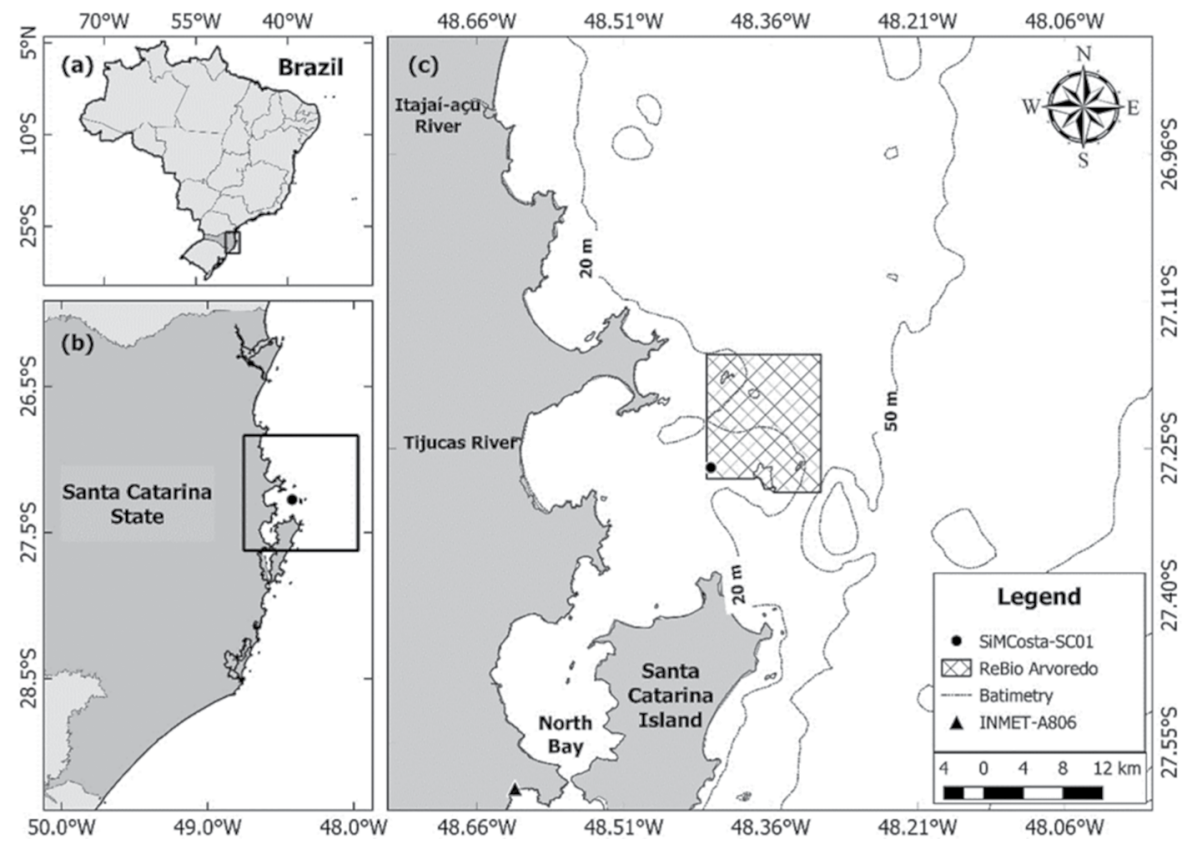

Figure 1. The study area. Brazil's reference map (a), subset area over the central coast of Santa Catarina State (b). The study area covered by satellite sensors (c). The limits of the Rebio Arvoredo are shown in the hatched area. The location of buoy SiMCosta SC01 (black dot) is shown at the bottom left corner of the Rebio Arvoredo. Tijucas river is the closest freshwater outflow in the vicinities of the buoy. 


\section{SATELLITE-DERIVED CHLOROPHYLL-A CONCENTRATION}

The satellite dataset was obtained for the same period of in situ dataset through a request form at NASA's OceanColor website (http://oceancolor.gsfc. nasa.gov/) for Moderate Resolution Imaging spectroradiometer (MODIS), onboard Aqua and Terra satellites, and Visible Infrared Imaging Radiometer Suite (VIIRS) aboard satellites SNPP and NOAA-20. We used MODIS and VIIRS data with $1 \mathrm{~km}$ and 750 meters of spatial resolution, respectively. The satellite dataset was composed by daily Local Area Covered (LAC) Level 2 product suite images of near-surface chlorophyll-a concentration data (hereinafter called $C_{\text {sat }}$ ). The $C_{\text {sat }}$ data was estimated by a default algorithm that merges the Color Index $(\mathrm{Cl})$ algorithm of $\mathrm{Hu}$ et al. (2012) and OCx (OC3/OC4) band ratio algorithm of O Reilly (2000). An empirical relationship derived from in situ measurements of $\mathrm{Chl}-a$ concentration and remote sensing reflectances $\left(R_{r s}\right)$, obtained by radiometers in the region of the blue $\left(\lambda_{\text {blue }}\right)$ and green $\left(\lambda_{\text {green }}\right)$ bands of the visible spectrum, returns $C_{\text {sat }}$ (in $\mathrm{mg} \mathrm{m}^{-3}$ ) in the surface layer of the sea. The algorithm is applicable to all current "sea color" sensors (https:// oceancolor.gsfc.nasa.gov/atbd/chlor_a/).

The OCx algorithm (Eq. 1) is a fourth order polynomial relationship between a ratio of $R_{r s}$ and concentration of Chl- $a$, where the ratio $R_{r s}\left(\lambda_{\text {blue }}\right) / R_{r s}\left(\lambda_{\text {green }}\right)$ must be the maximum band ratio (MBR) value for the wavelengths existing in these bands (Eq. 2). The coefficients a0 to a4 to estimate $C_{\text {sat }}$ for each sensor are specified in Table 1.

$$
\begin{gathered}
\log _{10}\left(C_{\text {sat }}\right)=a_{0}+\sum_{\mathrm{n}=1}^{4} a_{i}=\operatorname{MBR}^{i}(\text { eq.1 }) \\
\mathrm{MBR}=\log _{10}\left(\frac{\operatorname{Rrs}(\text { גblues })}{\operatorname{Rrs}(\lambda \text { green })}\right)(\mathrm{e} .2)
\end{gathered}
$$

The reflectance wavelengths used for current implementation of the standard $C_{\text {sat }}$ algorithm for MODIS (OC3M) were $443 \mathrm{~nm}, 488 \mathrm{~nm}, 547 \mathrm{~nm}$, and for VIIRS (OC3V) were $443 \mathrm{~nm}, 486 \mathrm{~nm}$, and 550nm.

\section{Quality control of Chl-a fluorescence datA}

Prior to any analysis, the quality of $F_{\text {chl-raw }}$ was accessed based on the recommendations of the US Integrated Ocean Observing System (US IOOS) Quality Assurance / Quality Control of Real-Time Oceanographic Data (QARTOD) project. Several sequential tests were performed in order to filter spurious $F_{\text {chl-raw }}$ data that are commonly obtained by autonomous sensors. Those tests are fully described on the Ocean Optical Data Handbook (U.S. IOOS, 2017) to guide real-time data quality control testing. The quality control tests recommended by U.S. IOOS (2017) follow a hierarchical sequence of 13 tests divided into 3 groups. Group I require five tests for real-time data monitoring and telemetry, other five strongly recommended tests at group II for quality control, and group III contains three suggested tests (Table 2). Among the five tests presented in Group I, only test number 4 was applied. The other tests were made by the SiMCosta team before the download of the data. Tests 3 and 5 of group I and test 6 of group II were not necessary because the samples were always acquired at the same place and depth. Test 7 was not performed because climatological chlorophyll- $a$ data for the region is non-existent, but the upper and lower limit values for $F_{\text {chl-raw }}$ were defined at 0.02 and 50 $\mathrm{mg} \mathrm{m}^{-3}$ respectively due to sensors range. Values below 0.02 and above $50 \mathrm{mg} \mathrm{m}^{-3}$ were excluded.

Optical data may show peaks of variation due to the presence of particulate aggregates in water (e.g. Briggs et al. 2011), hence, test 8 was applied to identify and remove this spurious data. For each $\mathrm{N}$ value in time series, this test determines if there is a $\mathrm{N}-1$ data peak by subtracting the midpoint from $\mathrm{N}-2$ and $\mathrm{N}$ assuming the absolute value of that amount to check whether it exceeds a low or high limit. The lower and upper limits for $F_{\text {chl-raw }}$ values were determined from the mean value plus three times the standard deviation of fluorescence data for the entire time series. Values that did not reach any limit were considered

Table 1. Specification of spectral band and coefficients used in the OCx algorithm for MODIS and VIIRS sensors.

\begin{tabular}{lcccccccc}
\hline Sensor & Algorithm & Blue & Green & a0 & a1 & a2 & a3 & a4 \\
\hline MODIS & OC3M & 443,488 & 547 & 0.2424 & -2.7423 & 1.8017 & 0.0015 & -1.2280 \\
VIIRS & OC3V & 443,486 & 550 & 0.2228 & -2.4683 & 1.5867 & -0.4275 & -0.7768
\end{tabular}

Source: https://oceancolor.gsfc.nasa.gov/atbd/chlor_a/ 
Table 2. Description of tests used in QUARTOD for time series data quality control.

\begin{tabular}{|c|c|c|c|}
\hline Group & $\begin{array}{l}\text { Test } \\
\text { number }\end{array}$ & Test name & Description \\
\hline \multirow[t]{5}{*}{ I } & 1 & Timing/Gap & Check time of data received by telemetry \\
\hline & 2 & Syntax & $\begin{array}{l}\text { Checks the structure of the message received by } \\
\text { telemetry }\end{array}$ \\
\hline & 3 & Location & Checks the geographical location of data. \\
\hline & 4 & Gross Range & Checks if data exceeds equipment limits \\
\hline & 5 & Decreasing Radiance, Irradiance, and PAR & Checks if parameters decrease with depth \\
\hline \multirow[t]{5}{*}{$\|$} & 6 & Photic Zone limit for Radiance Irradiance, and PAR & Checks if the parameters are below the photic zone \\
\hline & 7 & Climatology & Checks if parameter is within seasonal expectations \\
\hline & 8 & Spike & $\begin{array}{l}\text { Checks if the parameter exceeds a limit on adjacent } \\
\text { data }\end{array}$ \\
\hline & 9 & Rate of Change & $\begin{array}{l}\text { Checks whether the parameter has increased too } \\
\text { much or too low for a given time }\end{array}$ \\
\hline & 10 & Flat Line & Checks whether data value does not vary over time \\
\hline \multirow[t]{3}{*}{ III } & 11 & Multi-Variate & Comparison with other variables \\
\hline & 12 & Attenuated Signal & Checks for inappropriate time series variation \\
\hline & 13 & Neighbour & Check data similarity compared to nearby sensors \\
\hline
\end{tabular}

good. Values within the limits were considered suspect and values above the two limits were considered bad and excluded.

To verify the rates of change in the time series, test 9 was applied. This test inspects a time series to identify a time change index that exceeds a threshold value. The limit value determined for this test was 4 $\mathrm{mg} \mathrm{m}^{-3}$ per hour and represents a variation of 3 standard deviations of the complete series over a onehour interval. Values below the stipulated limit were considered good data. Values above the stipulated limit were considered suspect and excluded.

Test 10 has been applied to check for data records that do not vary with time. This attempts to inspect a time series to identify values that are not within a limit for a period used by the operator. For this test, a threshold period of 3 and 6 hours was stipulated without variation over than $0.01 \mathrm{mg} \mathrm{m}^{-3}$. If the data did not vary by more than $0.01 \mathrm{mg} \mathrm{m}^{-3}$ over a 3-hour period, the data was considered suspect. If this inheritance exceeded 6 hours, the data was considered bad and excluded from the time series. Finally, a hierarchical sequence of QARTOD tests performed in this study followed the order: 4, 8, 9 and 10 presented at Table 2. The approved chlorophyll- $a$ from fluorescence data will be denominated hereafter as $F_{c h}{ }^{\circ}$

\section{NONPHOTOCHEMICAL QUENCHING CORRECTING OF CHLO- ROPHYLL-A FROM FLUORESCENCE}

The measurement of chlorophyll- $a$ concentration using in situ fluorescence suffers a major problem due to nonphotochemical quenching (NPQ) processes. The overall consequence of this is the suppression of fluorescence emission under high light intensity. This NPQ mechanism helps phytoplankton cells to protect themselves when light energy exceeds their capacity of light utilization (Behrenfeld et al., 2009). During this photo-protection period, photosynthesis is inhibited and fluorescence yield drops (Müller et al., 2001), therefore, $F_{c h l}$ does not reflect the content of chlorophyll- $a$ concentration in the phytoplankton cells. Several methods have been proposed to correct the NPQ effect and retrieve the actual $\mathrm{Chl}-a$ concentration. Most of them follow two steps: (i) compare the fluorometric reading (in $\mathrm{mg} \mathrm{m}^{-3}$ ) with $\mathrm{Chl}-a$ concentration determined by either high performance liquid chromatography (HPLC) analysis or fluorometric measurement in laboratory, which ensure that $F_{c h l}$ is appropriately calibrated; (ii) correction of quenching based on measurements made by the in situ fluorometer at night or at some depth where the NPQ effect could be neglected. 
The WQM sensors acquired simultaneously by SiMCosta were distributed in three different places: Rio Grande (RS), São Sebastião (SP) and Florianópolis (SC). The relationship between extracted chlorophyll- $a$ and in situ WQM measurements were processed in the Centro de Biologia Marinha (CEBIMar) of Universidade de São Paulo (USP). Water samples were collected near the buoy SiMCosta SP01, moored at 300m from CEBIMar in São Sebastião (SP), always around 9am to minimize possible changes in chlorophyll- $a$ from fluorescence measurements due to high solar irradiance. The extracted chlorophyll- $a$ concentrations were read on a bench fluorimeter (Turner Designs model Trilogy), equipped with filters and lamps, following the method of Welschmeyer (1994). The relationship between unquenched $F_{c h l}$ and extracted chlorophyll- $a$ is quite robust ( $r=0.90$, $\mathrm{N}=23, p<0.05)$ and obeys the following relationship

$$
C_{\text {flu }}=1.55 F_{\text {chl }}(\text { unquenched })(\mathrm{eq} .3)
$$

where $C_{f u}$ stands for the extracted chlorophyll- $a$ concentration (Bellini and Ciotti, unpublished data). This calibration is absolutely necessary to convert Chl- $a$ concentrations determined by the WQM fluorometers into chlorophyll concentration values. Roesler et al (2017) presented a global validation data set for the WQM WET Labs series of chlorophyll- $a$ fluorometers. Their results were based on a comparison between HPLC and in situ fluorescence match ups after removing the NPQ in fluorescence readings. The authors suggested a factor of 2 to the factory calibrated Chl- $a$ estimates for these WQM WET Labs sensors (Roeslser et al, 2017). The slope of 1.55, obtained at CEBIMAR, was used to convert the $F_{c h l}$ corrected for quenching to chlorophyll- $a$ concentration and the result parameter was denominated as $C_{f l u^{\circ}}$

\section{QUALITY CONTROL OF SATELLITE-DERIVED CHLOROPHYLL-A CONCENTRATION}

The quality of the $C_{\text {sat }}$ estimates were assessed using the flags contained as metadata in the products made available by the Ocean Biology Distributed Active Archive Center (OB. DAAC) of NASA. The following flags (Table 3 ) were used to exclude doubtful pixels in each of the images analyzed: atmospheric correction failure (ATMFAIL), pixel over land (LAND),
Table 3. Description of flags used in the satellite data quality control procedure.

\begin{tabular}{ll}
\hline Flags & Description \\
\hline ATMFAIL & Atmospheric correction failure \\
LAND & Pixel is over land \\
HILT & Observed radiance very high or saturated \\
CLDICE & Probable cloud or ice contamination \\
STRAYLIGHT & Probable stray light contamination \\
\hline
\end{tabular}

Source: https://oceancolor.gsfc.nasa.gov/atbd/ocl2flags/

observed radiance remarkably high or saturated (HILT) and probable cloud or ice contamination (CLDICE). The usage of probable stray light contamination (STRAYLIGHT) flag over a $3 \times 3$ pixel window matchup was also evaluated due to highly occurrence of good pixels masked by it. This quality control processing was implemented for all $C_{\text {sat }}$ data before any matchup analysis took place.

\section{IN SITU AND SATELLITE CHLOROPHYLL-A MATCHUPS}

Satellite chlorophyll- $a$ estimates between 2017, February 22 and 2019, November 17 were used in this work due to the availability of in situ data. To avoid the use of doubtful data through validation procedures highlighted by Bailey and Werdell (2006), this study adopted the subsequent criteria in the matchups. First of all, the quality flags were used to check all $C_{\text {sat }}$ data prior to any analysis. The following flags were applied for L2 level data: ATMFAIL, LAND, HILT, CLDICE. In addition, the flag STRAYLIGHT was tested from its non-application until all pixels were approved. This last flag was considered to evaluate if the exclusion of unreliable data was not overestimated. A window of $3 \times 3$ pixels was fixed centered at SiMCosta-SC01 moored buoy position. We present here the results both with non- application of STRAYLIGHT flag and with application of it for more than 5 valid pixels in the $3 \times 3$ pixels window. The coefficient of variance (CV) was computed for each window as the spatial uniformity criterion for matchups. High CV indicates high variability within selected pixels and this effect could probably be caused by frontal zones or cloud edges. Those $3 \times 3$ pixel windows that presented CV value larger than 0.15 were excluded and, for the remaining ones, the median value was calculated. Finally, the absolute time interval between satellite overpass 
and in situ fluorescence measurements should be less than 1 hour, which is more restrict than the criteria described in Bailey and Werdell (2006) due to the availability of in situ data. In case of two $C_{f l u}$ measurements within the fixed +- 1 hour interval, their mean value was used in the matchup procedure.

In this work, we have processed 5,074 L2 images (Table 4), which were downloaded from http://oceancolor.gsfc.nasa.gov. The software Windows Image Manager (WIM) and Python programming language were used to execute all match-up processing steps presented above and summarized in the flowchart shown in Figure 2.

\section{Algorithms Performance Evaluation}

A variety of statistical and graphical criteria were used to evaluate the performance of satellite $\mathrm{Chl}-a$ algorithms. This study followed some recommendations by Seegers et al. (2018) and Pereira et al (2018). The performance of each algorithm was evaluated through statistical comparisons based on log-transformed data. The following metrics were used to assess the performance of each $\mathrm{Chl}-a$ algorithm: slope and intercept of the reduced major axis linear regression analysis, coefficient of determination $\left(R^{2}\right)$, root mean square error (RMSE, equation 4), BIAS (equation 5), mean absolute error ( $M A E$, equation 6), relative percent difference (RPD, equation 7) and absolute percent difference (APD, equation 8 ).

$$
\begin{aligned}
& \mathrm{RMSE}=\sqrt{\frac{\sum_{\mathrm{n}=1}^{N}=\left(\log _{10} e_{n}-\log _{10} o_{n}\right)^{2}}{\mathrm{~N}}}(\mathrm{eq.4}) \\
& \mathrm{BIAS}=10^{\wedge}\left(\frac{\sum_{n=1}^{N} \log _{10}\left(e_{n}\right)-\log _{10}\left(o_{n}\right)}{N}\right)(\mathrm{e} q .5) \\
& \mathrm{MAE}=10^{\wedge}\left(\frac{\sum_{n=1}^{N}\left|\log _{10}\left(e_{n}\right)-\log _{10}\left(o_{n}\right)\right|}{N}\right)(\mathrm{e} q .6) \\
& \mathrm{RPD}=\frac{\sum_{n=1}^{N} \frac{\left(\log _{10}\left(e_{n}\right)-\log _{10}\left(o_{n}\right)\right)}{\log _{10}\left(o_{n}\right)}}{N} \times 100(\mathrm{e} q .7)
\end{aligned}
$$

$\mathrm{APD}=\frac{\sum_{n=1}^{N} \frac{\left|\log _{10}\left(e_{n}\right)-\log _{10}\left(o_{n}\right)\right|}{\log _{10}\left(o_{n}\right)}}{N} \times 100(\mathrm{e} q .8)$

In the above equations, $o_{n}$ and $e_{n}$ are respectively $C_{\text {flu }}$ (observed) and $C_{\text {sat }}$ (estimated) data, and are their respective means. Equations 4, 5, 6, 7 and 8 were used for log-transformed chlorophyll- $a$ data.

\section{RESULTS}

\section{IN SITU CHLOROPHYLL-A FROM FLUORESCENCE}

The hourly $F_{c h l}$ data collected over a period of almost 3 years shows that several continuous gaps exist due to the maintenance procedure when all oceanographic sensors were taken to laboratory for inspection and clearance (Figure 3). The total period of maintenance corresponds to approximately $27 \%$ of the entire period. From the $73 \%$ of $F_{\text {chl-raw }}$ data, only $1.3 \%$ was filtered out by the QARTOD data quality control procedure, which confirms the high quality of the fluorescence data. The $F_{c h l}$ time series spans from Feb 2017 to Nov 2019 (Figure 3). Table 5 shows a statistical description of qualified and $C_{f l u}$ data.

\section{SURFACE WATER MASSES}

The collection of data by the WQM sensor also includes both sea surface temperature and salinity. Figure 4 shows TS diagrams with $F_{c h l}$ (Figure 4a) and the date (Figure 4b) as a third variable in the diagrams. Most of salinity values ( $92 \%$ of the data) were above 32 , showing that estuarine waters rarely reached the SiMCosta-SC01 buoy, except for April 2017 when the Tijuca river plume decreased the salinity (17).

\section{THE QUENCHING CORRECTION PROCEDURE}

The observed decrease in fluorescence values in the real environment appears when the phytoplankton cells absorb sunlight energy but photoprotective mechanisms present in phytoplankton cells avoid photodamage

Table 4. Number of MODIS-Aqua, MODIS-Terra, VIIRS-SNPP and VIIRS-JPSS1 ocean color images investigated in this study. The Level 2 images contain calibrated and geolocated radiances, chlorophyll, and quality flags.

\begin{tabular}{lccccc}
\hline Year & MODIS-Aqua & MODIS-Terra & VIIRS-SNPP & VIIRS-JPSS1 & Total \\
\hline $\mathbf{2 0 1 7}$ & 376 & 395 & 372 & 25 & 1168 \\
$\mathbf{2 0 1 8}$ & 460 & 487 & 573 & 495 & 2063 \\
$\mathbf{2 0 1 9}$ & 412 & 443 & 1440 & 494 & 1844 \\
TотAL & 1248 & 1325 & & 1062 & 5074 \\
\hline
\end{tabular}




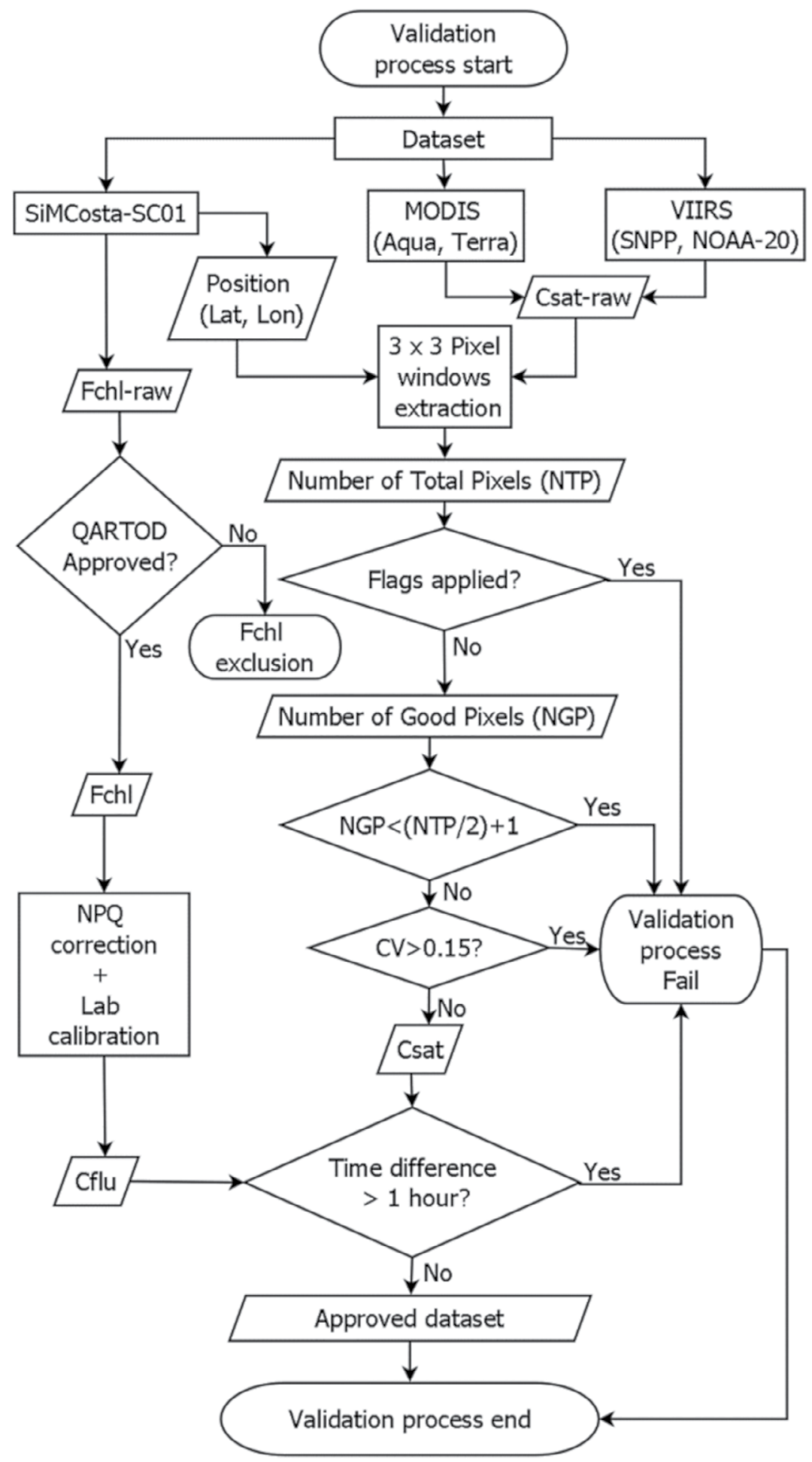

Figure 2. Flowchart adopted in this work to evaluate satellite chlorophyll- $a$ concentration algorithms. Adapted from Bailey and Werdell (2006). 


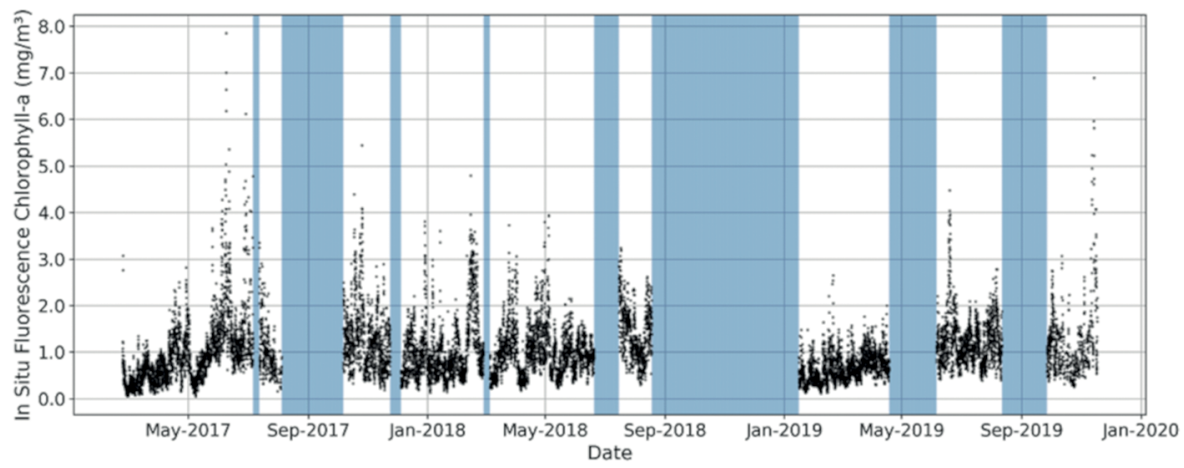

Figure 3. Temporal series of hourly Fchl data (black dots) approved by the SiMCosta data quality control system. The gaps (blue stripes) correspond to $27 \%$ of the entire dataset, and usually they are associated with maintenance of sensors and/or electrical failure of the power system of the SiMCosta-SC01 buoy.

Table 5. Number of $C_{f l u}$ measurements, minimum, mean, maximum and standard deviation of $C_{f l u}$ data in 2017, 2018 and 2019. The period of data collection spans from Feb 2017 to Nov 2019.

\begin{tabular}{lccccc}
\hline Year & Number of samples & Minimum $\left(\mathbf{m g ~ m}^{-\mathbf{3}}\right)$ & Mean $\left(\mathbf{m g ~ m}^{\mathbf{3}}\right)$ & Maximum $\left(\mathbf{m g ~} \mathbf{~ m}^{-\mathbf{3}}\right)$ & $\begin{array}{c}\text { Standard } \\
\text { deviation }\left(\mathbf{m g ~} \mathbf{~}^{-3}\right)\end{array}$ \\
\hline 2017 & 5139 & 0.11 & 1.73 & 9.58 & $1,00$. \\
2018 & 4724 & 0.31 & 1.88 & 7.43 & 0.94 \\
2019 & 4237 & 0.22 & 1.61 & 9.01 & 0.82 \\
Total & $\mathbf{1 4 1 0 0}$ & $\mathbf{0 . 1 1}$ & $\mathbf{1 . 7 4}$ & $\mathbf{9 . 5 8}$ & $\mathbf{0 . 9 3}$ \\
\hline
\end{tabular}

under excessive sunlight. Therefore, daylight $F_{c h l}$ values are usually smaller than nighttime values (Figure 5). The influence of NPQ on $F_{c h l}$ estimates can be also clearly seen when each $F_{c h l}$ measurement is normalized by their respective nightly maximum value (Carberry et al., 2019). Figure 6 shows an example of the NPQ effect on daytime $F_{c h l}$ recorded by the WQM sensor at SiMCosta SC01. The dependence of $F_{c h l}$ on PAR was noticeable when PAR values were above $200 \mathrm{Wm}^{-2}$. Furthermore, such dependence is not contingent on the hour of day (Figure 6a) since measurements can be made in very cloudy days when PAR measurements are relatively low. On the other hand, after NPQ correction, the ratio of $F_{c h l}$ to its respective maximum nighttime value, showed only a small dependence on PAR after $1200 \mathrm{Wm}^{-2}$ (Figure 6b). The overall behavior of NPQ-corrected $F_{c h l}$ with solar irradiance data (Figure $6 \mathrm{~b}$ ) suggests a successful approach to correct quenching on in situ chlorophyll-a from fluorescence values.

\section{Evaluation of operational CHLOROPHYLl CONCEN- TRATION ALGORITHMS}

The validation criteria adopted here to evaluate operational $\mathrm{Chl}-a$ algorithms allowed us to obtain 506 paired of $C_{f u}$ and $C_{\text {sat }}$ data, being 222 pairs for
MODIS and 284 for VIIRS. This relatively high number of paired chlorophyll values was achieved when flags ATMFAIL, LAND, CLDICE, HILT were applied. The frequency distribution of $C_{f l u}$ and $C_{\text {sat }}$ paired data are quite similar (Figure 7), where mean and standard deviation values for $C_{f u}$ and $C_{\text {sat }}$ were $1.83 \pm 0.86$ and 1.76 $\pm 0.87 \mathrm{mg} \mathrm{m}^{-3}$, respectively. Table 6 provides the basic statistical data $C_{f l u}$ and $C_{\text {sat }}$ paired data for MODIS and VIIRS sensors. If we use the STRAYLIGHT flag, there is a substantial reduction in the number of $C_{\text {sat }}$ data. For instance, if we consider that at least 5 out of 9 pixels (window size) are not contaminated by straylight, then the number of paired chlorophyll data decreases to 56 pairs for MODIS and 64 for VIIRS, and the mean and standard deviation values for $C_{f l u}$ and $C_{\text {sat }}$ were $1.76 \pm 0.72$ and $1.82 \pm 0.82 \mathrm{mg} \mathrm{m}^{-3}$, respectively.

\section{DISCUSSION}

\section{VARIABILITY OF SURFACE WATER MASS}

The studied region is regularly occupied by Subtropical Shelf Water (STSW) (Bordin et al, 2019) - a mixture of La Plata Plume Water (PPW) and Tropical Water (TW) (Moller et al, 2008) - with higher influence of PPW (TW) in wintertime (summertime) (Moller 

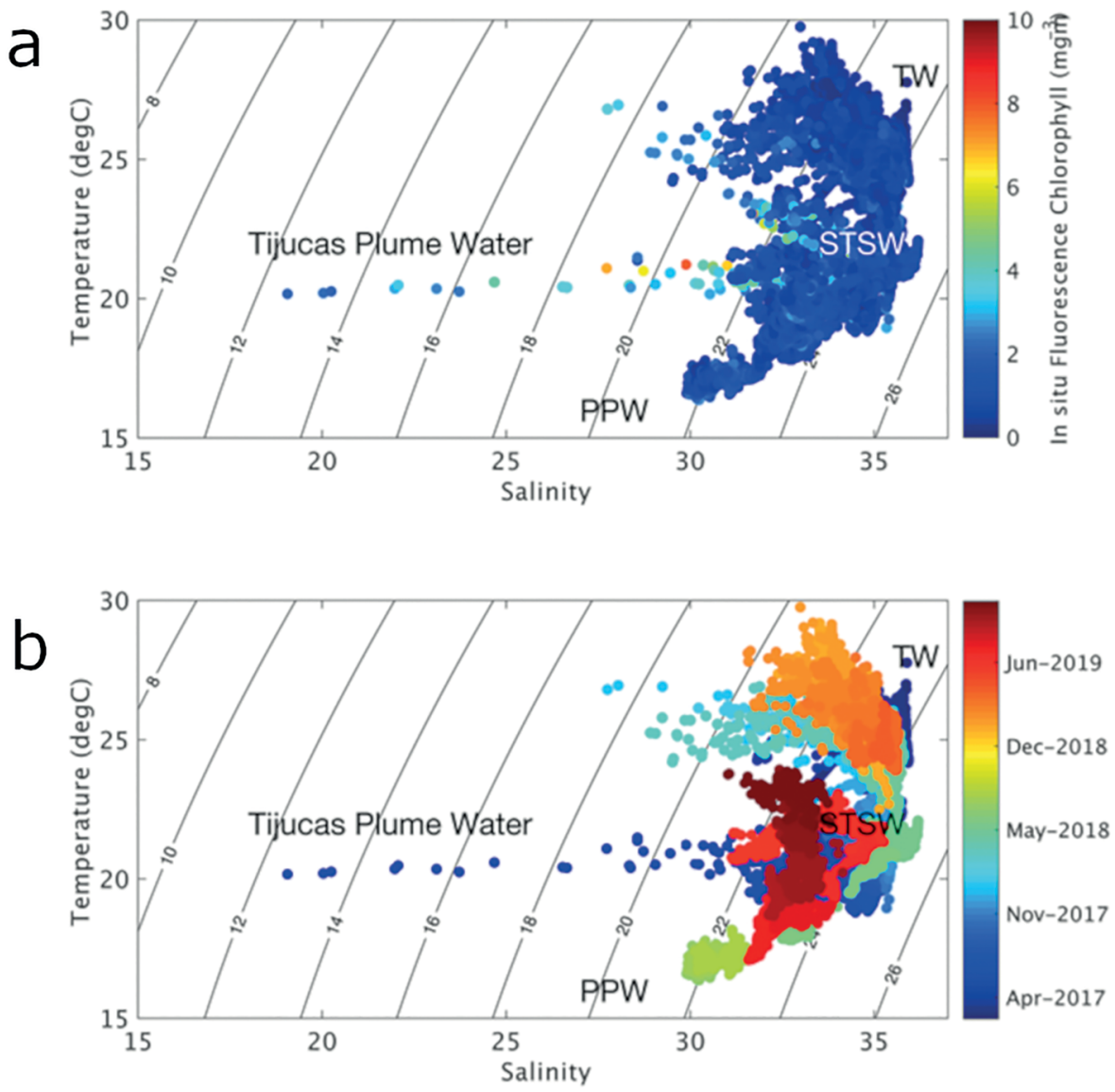

Figure 4. TS-fluorescence (a) and TS-time (b) diagrams. TW, STSW and PPW stand for Tropical Water, Subtropical Shelf Waters and La Plata Plume Water. The effect of the plume of Tijucas river on the local thermohaline properties is also shown.

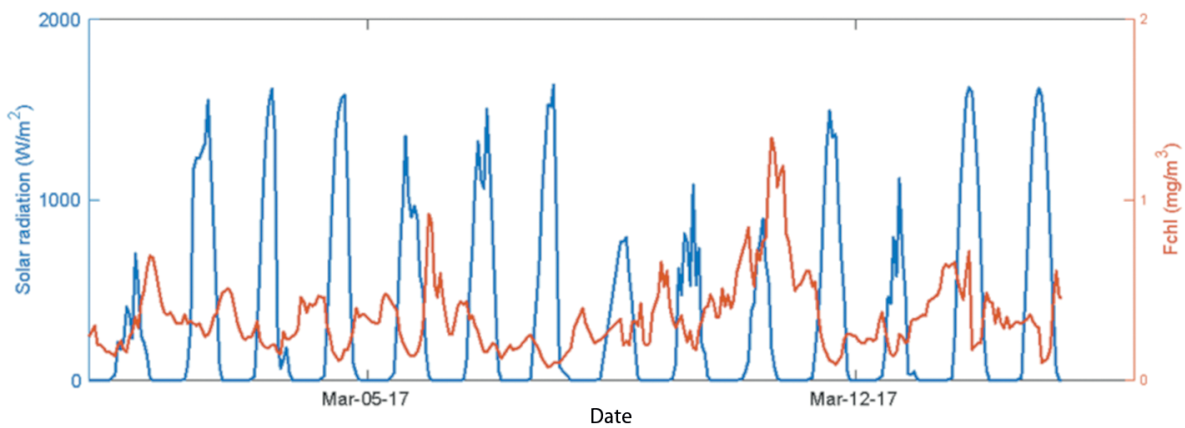

Figure 5. Evolution of hourly solar radiation and in situ chlorophyll- $a$ fluorescence $\left(F_{c h}\right)$ from March 1 to 14,2017 . The NPQ effect can be observed in daytime when fluorescence values decrease.

et al, 2008; Bordin et al 2019). The influence of PPW in the thermohaline properties occurred during wintertime (Figure 5b), when a series of cold frontal passages crossed the southern portion of Brazil and brought cold and less saline waters from the Uruguayan coast northwards along the Brazilian coast. The presence of colder and less saline waters of the La Plata plume over the southern Brazilian coast has been extensively studied (Piola et al, 2005; Moller et al, 2008, Garcia and Garcia, 2008; Bordin et al, 2019). The incursion of these waters along the southern inner shelf depends on the magnitude of the La Plata discharge and the intensity, 

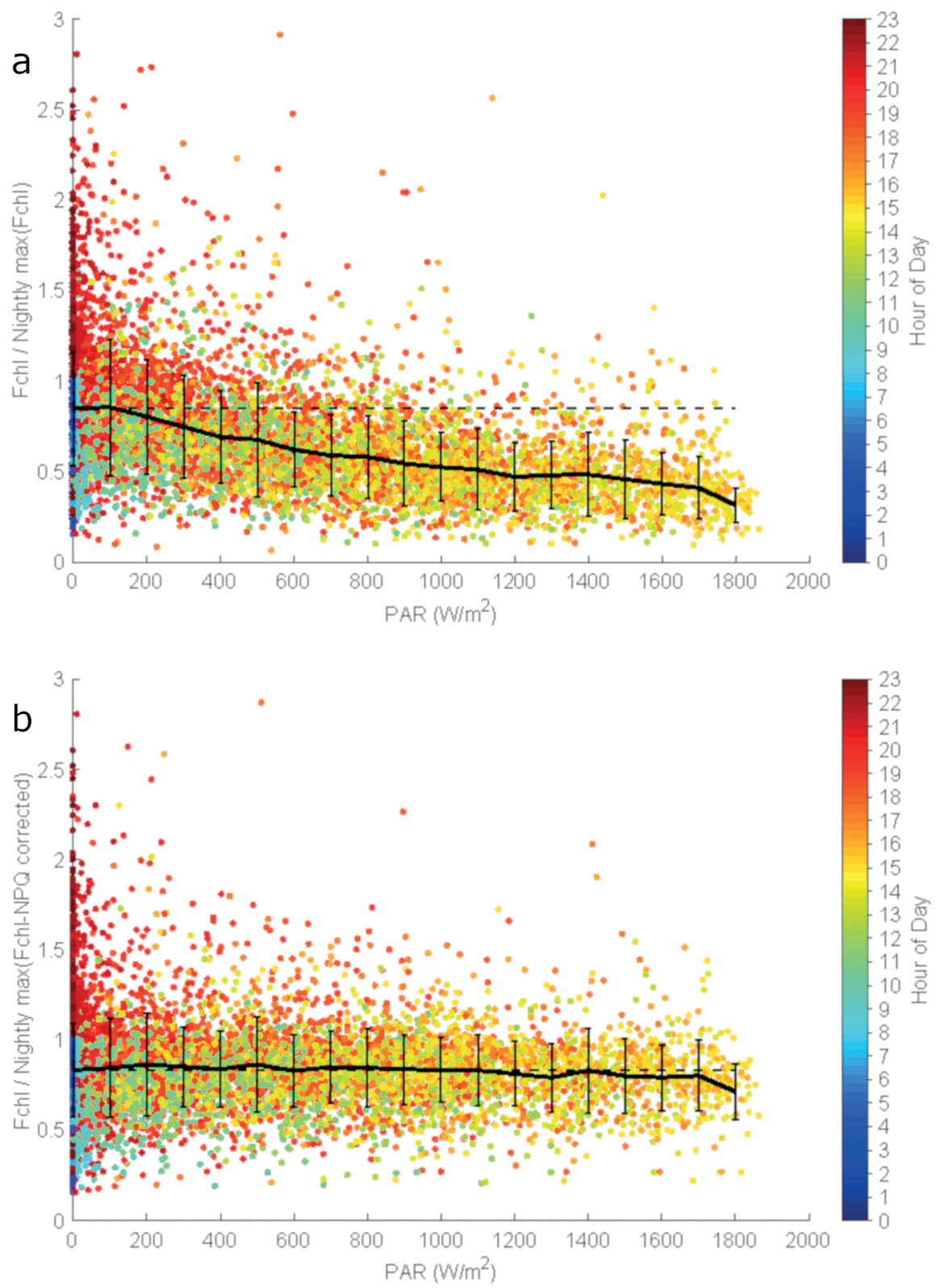

Figure 6. The ratio maximum nighttime $F_{c h l}$ to $F_{c h l}$ for non-quenching (a) and quenching-corrected (b) measurements as function of incident PAR over SiMCosta SC01. The dashed line represents the mean value of the ratio at nighttime when solar radiation is null. Median and standard deviation of $\mathrm{F}_{c h l}$ values are shown by solid black line and error bars, respectively, at PAR intervals of $100 \mathrm{~W} \mathrm{~m}^{-2}$. The colors are associated with the hour (GMT time) of the day.

direction and duration of the wind stress (Piola et al, 2005). TS-diagrams have shown that La Plata plume waters had a more pronounced influence in 2018 than in 2019 (Figure 5b). A close inspection of monthly mean sea surface temperature and chl- $a$ surface concentration images of July 2017, 2018 and 2019 (Figure 8) showed that indeed the stronger intrusion of cold and less saline waters happened in 2018 with higher chl- $a$ surface concentrations. Most of the time, the studied region was occupied by STSW water, with influence of TW in summer and PPW in wintertime. The Tijucas river outflow was reduced to the vicinities of its mouth, 


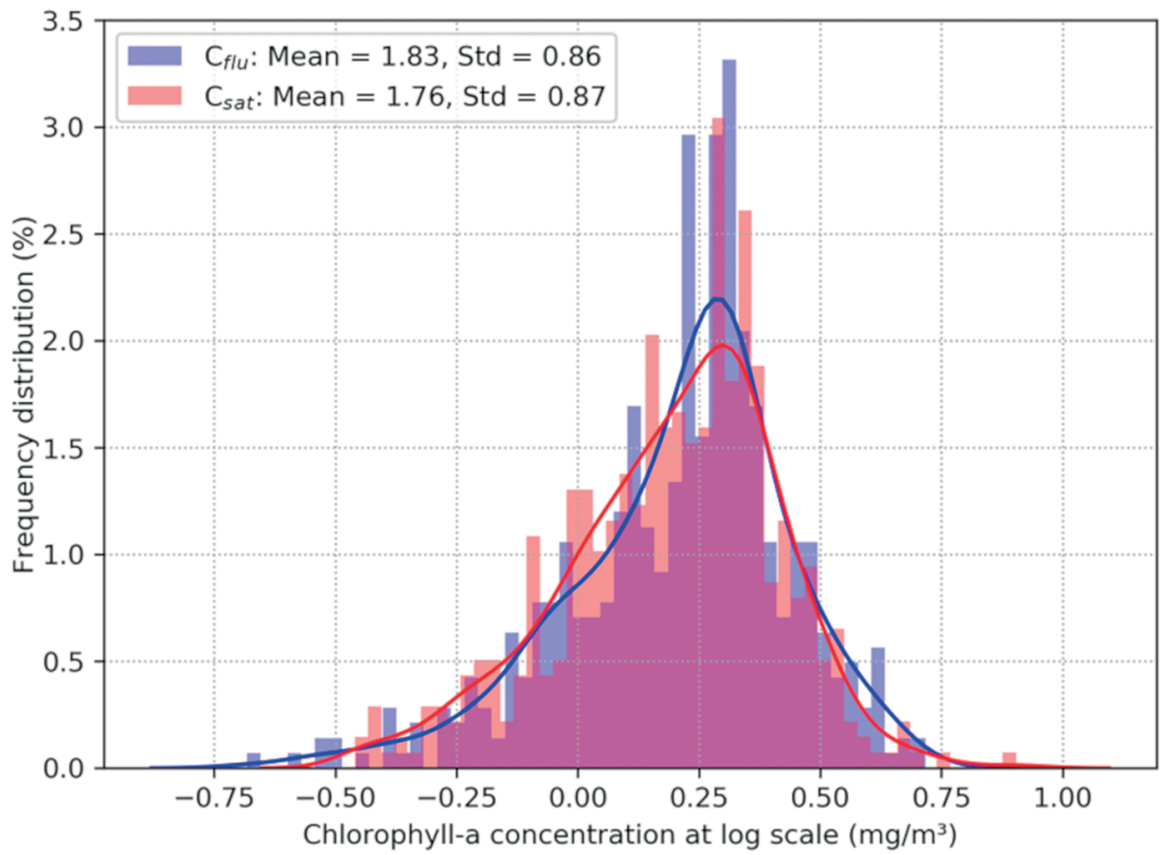

Figure 7. Distribution of 506 paired data which were considered valid for the match-up procedure between $\mathrm{C}_{\text {fu }}$ (blue color) and $\mathrm{C}_{\text {sat }}$ (orange color). The mean and standard deviation values for $C_{f l u}$ and $C_{\text {sat }}$ were $1.83 \pm 0.86$ and $1.76 \pm 0.87 \mathrm{mg} \mathrm{m}^{-3}$, respectively.

Table 6. Description of matchup results by each sensor.

\begin{tabular}{lcccccccccc}
\hline \multirow{2}{*}{ Sensor } & $\begin{array}{c}\text { Number } \\
\text { of } \\
\text { samples }\end{array}$ & Min & Max & Mean & Std & Min & Max & \multicolumn{2}{c}{$\mathbf{C}_{\text {flu }}\left(\mathbf{m g ~ m}^{-3}\right)$} & \multicolumn{3}{c}{$\mathbf{C}_{\text {sat }}\left(\mathbf{m g ~ m}^{-3}\right)$} \\
\hline MODIS & 222 & 0.21 & 4.60 & 1.81 & 0.83 & 0.37 & 5.79 & 1.97 & 0.85 \\
VIIRS & 284 & 0.26 & 5.22 & 1.84 & 0.88 & 0.35 & 8.02 & 1.59 & 0.84 \\
\hline
\end{tabular}

reaching the position of SiMCosta-SC01 buoy in a very rare occasion (Figure $5 \mathrm{a}$ and $5 \mathrm{~b}$ ). Therefore, in almost the entire period of study, the organic and inorganic material derived from Tijucas' outflow did not reach the near surface waters sensed by buoy SiMCosta-SC01.

\section{THE CORRECTION FOR NONPHOTOCHEMICAL QUENCHING}

In our study, we assumed that the variability of phytoplankton biomass at SiMCosta-SC01 is expected to occur on timescales longer than the diurnal cycle based on Dalbosco et al. (2020). The authors analyzed the contribution of tidal and meteorological forcing on the alongshore and cross-shore components of currents obtained by an ADCP installed close $(<5 \mathrm{~nm})$ to the SiMCosta-SC01 buoy in the Rebio Arvoredo region. They concluded that a predominance of southward flow (68.5\%) was found in the alongshore component, with an average of 0.18 $\mathrm{m} / \mathrm{s}$. The decomposition in variance of the barotropic component of current has shown that only $13 \%$ is due to tidal forcing, and $87 \%$ of the energy was on the subtidal frequency where winds are the most important forcing mechanism driving these shallow waters. Therefore, daylight fluorometric measurements could be replaced to a first approximation by interpolation between $F_{c h l}$ measurements at sunrise and sunset on a daily basis, which was successfully done in this study (see Figure 6b) to correct the NPQ effect on $F_{c h l}$ measurements.

In coastal waters, if advection of surface waters plays an import role in phytoplankton biomass variability within the diurnal cycle, then a complex procedure should be used to correct for the advection of water within the tidal cycle. For instance, Carberry et al. (2019) used the unquenched nighttime observations and measured velocity data to correct for both NPQ effect and local 

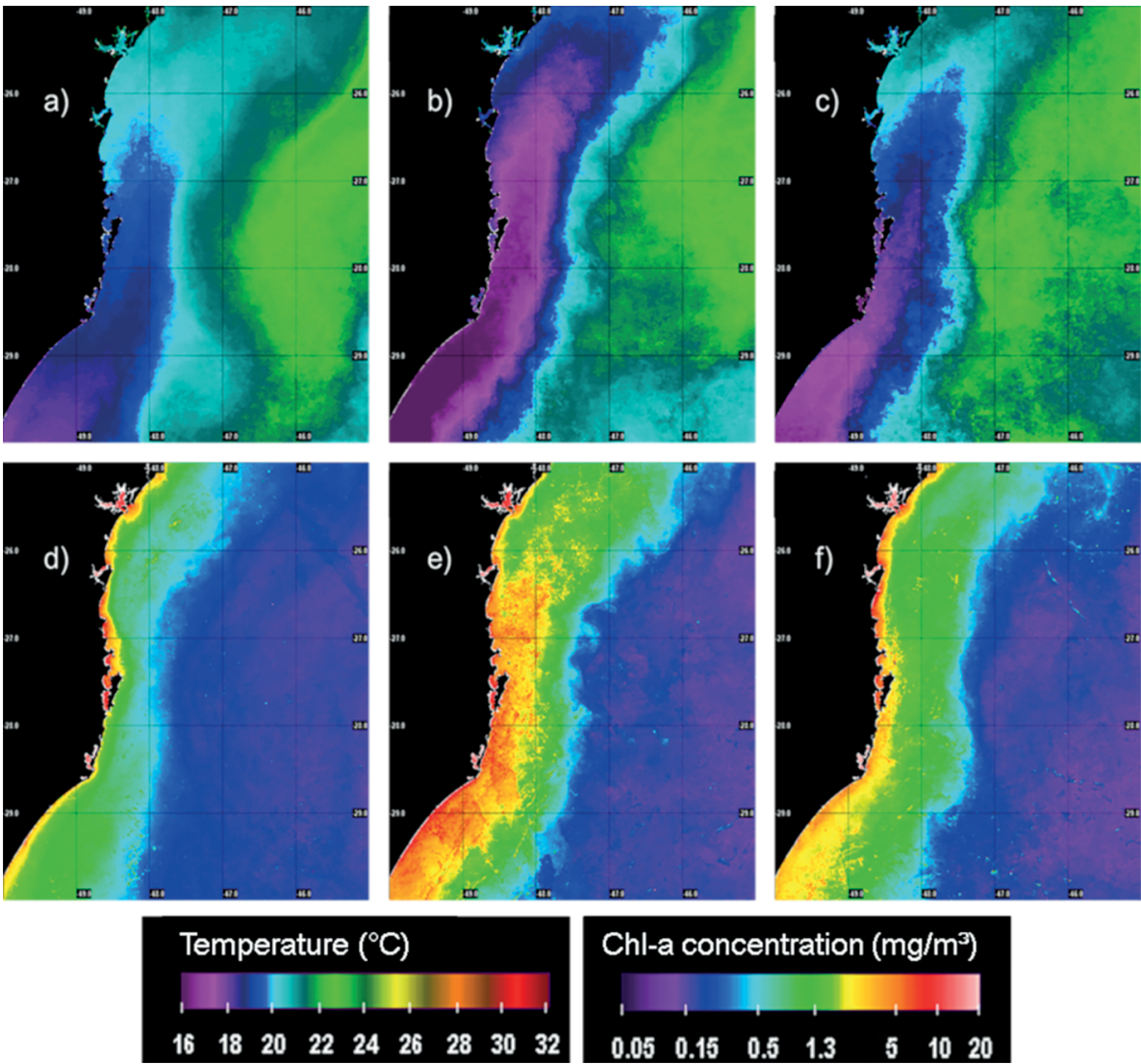

Figure 8. Monthly mean MODIS/VIIRS composite of daily sea surface temperature (SST) in July 2017 (a), July 2018 (b) and July 2019 (c) and monthly mean MODIS/VIIRS composite of daily chlorophyll-a surface concentration in July 2017 (d), July 2018 (e) and July 2019 (f). The SST images were derived from the NLSST algorithm and represent a composition of daily MODIS-Aqua, MODIS-Terra, VIIRS-JPSS and VIIRS-NOAA20.

advection in the tidally dominated narrow inlets that comprise Casco Bay in Maine (USA).

In open ocean waters, if $F_{c h l}$ is available for the entire water column, one can assume that fluorescence signal does not suffer from NPQ in deep water and the decrease of $F_{\text {chl }}$ occurs only at mixed layer (Sackmann et al., 2008). For instance, Xing et al (2018) have corrected the NPQ effect in thousands of fluorescence profiles measured by instrumented elephant seals in the Kerguelen region (Southern Ocean) by making an extrapolation of the deep fluorescence value toward the surface.

\section{ON the Validation of Satellite estimates of CHLOROPHYLL-A CONCENTRATION}

In this work, an effort was made to infer the consequences of using pixels contaminated and not contaminated by straylight. The overall values of the metrics used in the validation procedure here are quite similar (Table 7), either if we consider STRAYLIGHT flag off (Figure 9) or we use at least 5 pixels (in the $3 \times 3$ pixels window) not contaminated with STRAYLIGHT (Figure 10). Considering only Seegers (2018) suggested metrics and the results found without usage of STRAYLIGHT flag, MODIS data presented lower percentage error $(\mathrm{MAE}=1.34)$ than VIIRS $(\mathrm{MAE}=1.41)$ at log scale.

The high quality L2 images provided by the operational chlorophyll algorithm for MODIS and VIIRS sensors uses a $7 \times 5$ pixel window around the pixels classified as cloud to mask the straylight contamination (Feng and $\mathrm{Hu}, 2016)$. Usually, straylight can be noticeable in the vicinity of pixels masked as cloud or land and can extend for several pixels from the source. This $7 \times 5$ pixels straylight window in the masking method has been subject of analysis by several researchers (Sterckx et al, 2011; Jiang and Wang, 2013; Feng and $\mathrm{Hu}$, 2016). Feng and $\mathrm{Hu}$ (2016) suggested 
Table 7. The values of the metrics used to evaluate existing operational chlorophyll- $a$ algorithms. The results from the linear regressions between $C_{f l u}$ and $C_{s a t^{\prime}}$ either in linear or logarithm form, presented statistical significance at $90 \%$ level when straylight flags was not applied. Linear and Log10 stand for RMA linear regressions between $C_{f l u}$ and $C_{\text {sat }}$ and $\log _{10}\left(C_{f l u}\right)$ and $\log _{10}\left(C_{\text {sat }}\right)$, respectively.

\begin{tabular}{|c|c|c|c|c|c|c|c|c|c|c|}
\hline $\begin{array}{l}\text { Sensor } \\
\text { matchup } \\
\text { statistics }\end{array}$ & $\begin{array}{c}\text { Valid } \\
\text { Straylight } \\
\text { Flag }\end{array}$ & $\mathbf{N}$ & Slope & Intercept & $\mathbf{R}^{2 z}$ & $\begin{array}{c}\text { MAE } \\
\left(\mathrm{mg} \mathrm{m}^{-3}\right)\end{array}$ & $\begin{array}{c}\text { RMSE } \\
\left(\mathrm{mg} \mathrm{m}^{-3}\right)\end{array}$ & $\begin{array}{c}\text { BIAS } \\
\left(\mathrm{mg} \mathrm{m}^{-3}\right)\end{array}$ & APD (\%) & RPD (\%) \\
\hline \multirow{2}{*}{$\begin{array}{l}\text { MODIS } \\
\text { Log }\end{array}$} & $\begin{array}{c}\text { Not } \\
\text { applied }\end{array}$ & 222 & 0.92 & 0.06 & 0.96 & 1.34 & 0.05 & 1.11 & 115.78 & -30.25 \\
\hline & 5 & 56 & 0.86 & 0.08 & 0.93 & 1.25 & 0.06 & 1.14 & 79.12 & 7.65 \\
\hline \multirow[t]{2}{*}{ VIIRS Log } & $\begin{array}{c}\text { Not } \\
\text { applied }\end{array}$ & 284 & 0.97 & -0.06 & 0.88 & 1.41 & 0.06 & 0.86 & 149.99 & 1.51 \\
\hline & 5 & 64 & 0.96 & 0.02 & 1.00 & 1.34 & 0.01 & 1.01 & 174.25 & -115.26 \\
\hline
\end{tabular}
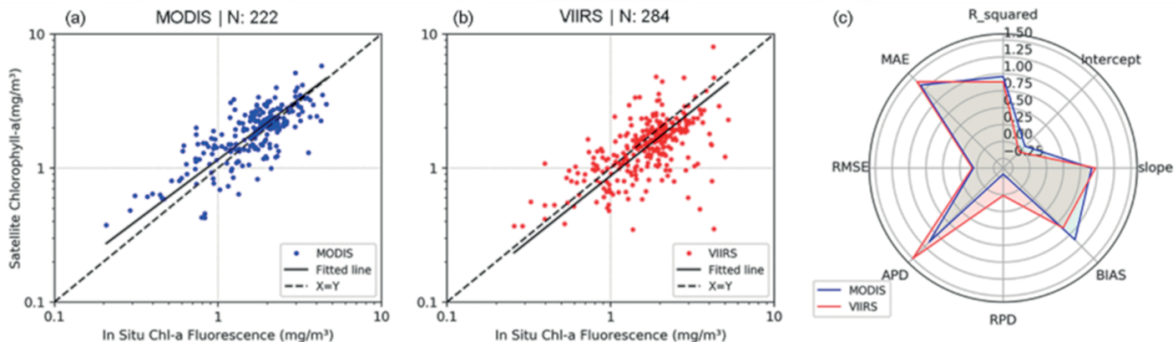

Figure 9. Comparisons between $C_{f l u}$ and $C_{\text {sat }}$ for sensor MODIS and VIIRS at logarithm scales ( $a$ and b) using no straylight flag. The star plots (c) of the metrics used to compare $C_{f u}$ and $C_{\text {sat }}$ at logarithm scales are also shown.
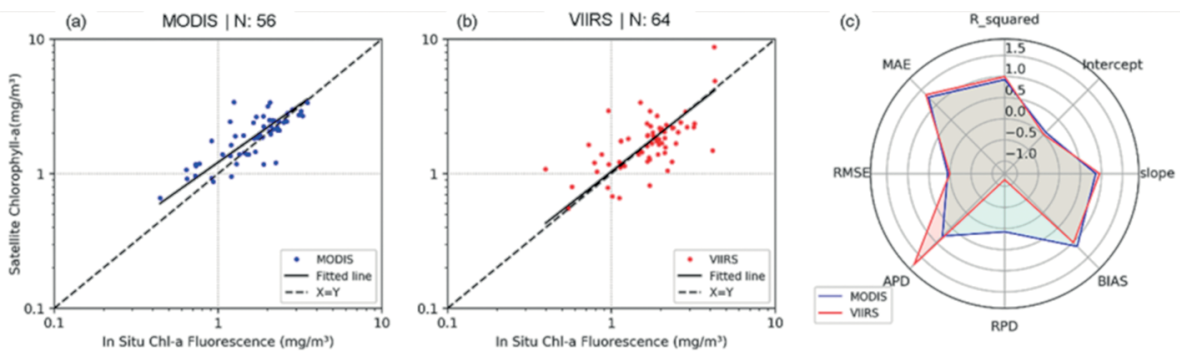

Figure 10. Comparisons between $C_{f l u}$ and $C_{\text {sat }}$ for sensor MODIS and VIIRS at logarithm ( $a$ and b) scales using straylight flags (at least 5 valid pixels). The star plots of the metrics used to compare $C_{f l u}$ and $C_{\text {sat }}$ at logarithm (c) scales are also shown.

that the current MODIS straylight masking 7x5 pixels window may be relaxed to $3 \times 3$ without losing data quality. Essentially, for MODIS and VIIRS (most sensors in fact) the STRAYLIGHT flag is effectively a dilation of the CLDICE (and/or HILT) flags.

Our results reinforce such change in the window size used by NASA operating chlorophyll algorithms to mask pixels contaminated by straylight. In addition, our results have also shown that the differences between $C_{\text {sat }}$ and $C_{f u}$ do not depend on PAR measurements (Figure 11a) and time of year (Figure 11b), which reflects the good correction for nonphotochemical quenching in the measurements of in situ chlorophyll-a from fluorescence data.

\section{CONCLUSION}

In this study, we investigated the uncertainties of standard chlorophyll- $a$ algorithms in the southern Brazilian inner shelf using both quality-controlled chlorophyll- $a$ concentration from in situ fluorescence and from satellite data.

We ended up with a time series of 14,100 hourly in situ chlorophyll- $a$ concentration from fluorescence to be compared with satellite-estimates. The very strict validation criteria adopted here to evaluate operational $\mathrm{Chl}-a$ algorithms allowed us to obtain 506 paired of $C_{f l u}$ and $C_{\text {sat }}$ data being 222 pairs for MODIS and 284 for VIIRS. The 

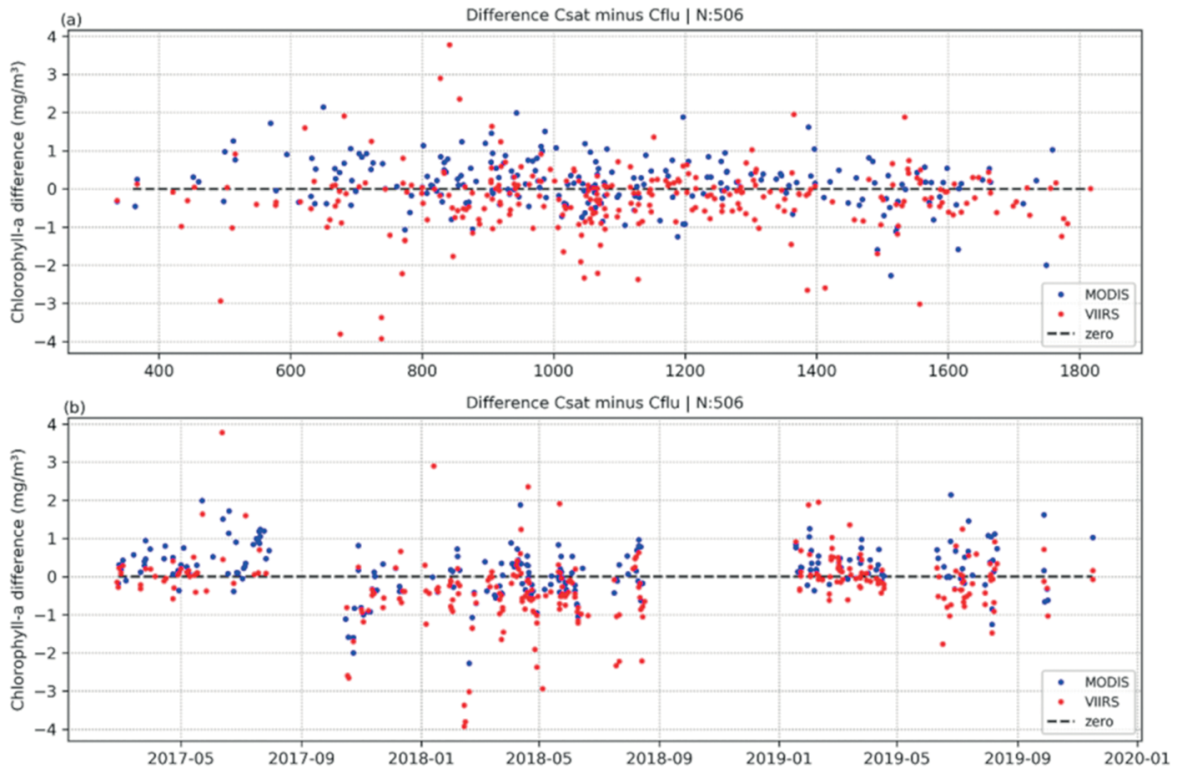

Figure 11. Dependence of the difference between $C_{s a t}$ and $C_{f l u}$ on PAR measurements (a) and along the nearly 3-year period (b).

MODIS algorithm yielded the best performance results, although VIIRS presented relatively good performance. Overall, the time series analysis of the in situ and satellitederived Chl-a values agreed well, which suggest the use of the standard MODIS and VIIRS chlorophyll algorithms for the region. The procedure adopted here to evaluate existing operational algorithms can be applied to other Brazilian coastal regions with relatively low turbid waters. Despite our results, the collection of in situ spectral reflectance data in conjunction with chlorophyll- $a$ concentration is highly desirable to create a regional algorithm to monitor $\mathrm{Chl}-a$ with higher accuracy.

\section{ACKNOWLEDGMENTS}

This work received funding from the Brazilian Coastal Monitoring System (SiMCosta) team and their support is gratefully acknowledged. SiMCosta is funded by Fundo Clima, the Ministry of Environment and the Ministry of Science, Technology and Innovation. A number of field assistants were involved in the deployment of the buoy SiMCosta SC01 and we are particularly grateful to all of them. A special thank you to Ella S. Pereira, national manager of SiMCosta. To A.M. Ciotti for the data of relationship between extracted chlorophyll- $a$ and in situ WQM measurements and for previously revising this manuscript. The US NASA space agency and Ocean Biology Processing Group (OBPG) is thanked for the easy access to MODIS and
VIIRS data. A crucial and indispensable thank you to the Federal University of Santa Catarina and to the Postgraduate Program in Oceanography that provided Gabriel S. de M. Silva the opportunity for a public and high-quality academic training. This scientific article is a contribution resulting from public investment in oceanography and emphasizes the importance of promoting R\&D in Brazil.

\section{AUTHOR CONTRIBUTIONS}

G.S.M.S.: Conceptualization, Data curation, Formal analysis, Methodology, Supervision, Validation, Writing Original Draft, Writing - Review \& Editing, Supervision.

C.A.E.G.: Conceptualization, Data curation, Formal analysis, Methodology, Supervision, Validation, Writing - Original Draft, Writing - Review \& Editing, Supervision, Funding acquisition.

\section{REFERENCES}

BAILEY, S. W. \& WERDELL, P. J. 2006. A multi-sensor approach for the on-orbit validation of ocean color satellite data products. Remote Sensing of Environment, 102(1-2), 12-23, DOI: https://doi.org/10.1016/j.rse.2006.01.015

BANKS, A. C., PRUNET, P., CHIMOT, J., PINA, P., DONNADILLE, J., JEANSOU, E., LUX, M., PETIHAKIS, G., KORRES, G., TRIANTAFYLLOU, G., FONTANA, C., ESTOURNEL, C., ULSES, C. \& FERNANDEZ, L. 2012. A satellite ocean color observation operator system for eutrophication assessment in coastal waters. Journal of Marine Systems, 94(Suppl 1), S2-S15, DOI: https:// doi.org/10.1016/j.jmarsys.2011.11.001 
BEHRENFELD, M. J., WESTBERRY, T., BOSS, E., O'MALLEY, R., SIEGEL, D., WIGGERT, J. D., FRANZ, B., FELDMAN, G., DONEY, S., MOORE, J., DALL'OLMO, G., MILLIGAN, A., LIMA, I. \& MAHOWALD, N. 2009. Satellite-detected fluorescence reveals global physiology of ocean phytoplankton [online]. Biogeosciences, 6(5), 779-794. Available at: https://aquila.usm.edu/ fac_pubs/1132 [Accessed: 05 Jun. 2019].

BLONDEAU-PATISSIER, D., GOWER J. F. R., DEKKER, A. G., PHINN, S R. \& BRANDO, V. E. 2014. A review of ocean color remote sensing methods and statistical techniques for the detection, mapping and analysis of phytoplankton blooms in coastal and open oceans. Progress in Oceanography, 123, 123-144, DOI: https://doi.org/10.1016/j.pocean.2013.12.008

BORDIN, L. H., MACHADO, E. C., CARVALHO, M., FREIRE, A. S. \& FONSECA, A. L. D. O. 2019. Nutrient and carbon dynamics under the water mass seasonality on the continental shelf at the South Brazil Bight. Journal of Marine Systems, 189, 2235, DOI: https://doi.org/10.1016/j.jmarsys.2018.09.006

BRASIL. 1990. Decreto $n^{\circ} 99.142$, de 12 de março de 1990. Cria, no Estado de Santa Catarina, a Reserva Biológica Marinha do Arvoredo, e dá outras providências. Diário Oficial da União, Brasília (DF), Seção 1, pp. 5005.

BRIGGS, N., PERRY, M. J., CETINIC, I., LEE, C., D'ASARO, E., GRAY, A. M. \& REHM, E. 2011. High-resolution observations of aggregate flux during a sub-polar North Atlantic spring bloom, Deep Sea Research Part I: Oceanographic Research Papers, 58(10), 1031-1039, DOI: https://doi.org/10.1016/j. dsr.2011.07.007

CAMPOS, P. C., MÖLLER, O. O., PIOLA, A. R. \& PALMA, E. D. 2013. Seasonal variability and coastal upwelling near Cape Santa Marta (Brazil). Journal of Geophysical Research: Oceans, 118(3), 1420-1433, DOI: https://doi.org/10.1002/jgrc.20131

CARBERRY, L., ROESLER, C. \& DRAPEU, S. 2019. Correcting in situ chlorophyll fluorescence time-series observations for nonphotochemical quenching and tidal variability reveals nonconservative phytoplankton variability in coastal waters. Limnology and Oceanography: Methods, 17(8), 462-473, DOI: https://doi.org/10.1002/lom3.10325

CARVALHO, J., SCHETTINI, C. \& RIBAS, T. 2010. Estrutura termohalina do litoral centro-norte catarinense. Brazilian Journal of Aquatic Science and Technology, 2(1), 181-197.

CASTRO FILHO, B. M. \& MIRANDA, L. B. 1998. Physical oceanography of the western Atlantic continental shelf located between $4 \mathrm{~N}$ and $34 \mathrm{~S}$ : Coastal segment $(4, \mathrm{~W})$. In: ROBINSON, A. \& BRINK, K. (eds.). The Sea. Oxford: John Wiley \& Sons, v. 11 , pp. 209-211.

CHANG, N. B. \& XUAN, Z. M. 2011. Exploring the nutrient inputs and cycles in Tampa Bay and coastal watersheds using MODIS images and data mining. In: GAO, W. \& SHAW, D. R. (eds.). Remote sensing and modeling of ecosystems for sustainability VIII, 8156C. Bellingham: SPIE Digital Library (The International Society for Optics and Photonics), v. 5884, DOI: https:// doi.org/10.1117/12.891871

CIOTTI, A. M., GARCIA, C. A. E. \& JORGE, D. S. F. 2010. Temporal and meridional variability of satellite-estimates of surface chlorophyll concentration over the Brazilian continental shelf. Pan-American Journal of Aquatic Sciences, 5(2), 236-253, DOI: https://panamjas.org/pdf_artigos/PANAMJAS_5(2)_236-253.pdf
CLARKE, G. L., EWING, G. C. \& LORENZEN, C. J. 1970. Spectra of backscattered light from the sea obtained from aircraft as a measure of chlorophyll concentration. American Association for the Advancement of Science, 167(3921), 1119-1121, DOI: https://www.jstor.org/stable/1728683

CLOERN, J. E., FOSTER, S. Q., KLECKNER, A. E. 2014. Phytoplankton primary production in the world's estuarine-coastal ecosystems. Biogeosciences, 11(9), 2477-2501, DOI: https://doi.org/10.5194/bg-11-2477-2014

CULLEN, J. J. 1982. The deep chlorophyll maximum: comparing vertical profiles of chlorophyll a. Canadian Journal of Fisheries and Aquatic Sciences, 39(5), 791-803, DOI: https://doi. org/10.1139/f82-108

CULLEN, J. J, CIOTTI, A. M., DAVIS, R. F. \& LEWIS, M. R. 1997. Optical detection and assessment of algal blooms. Limnology and Oceanography, 42(5 Pt 2), 1223-1239, DOI: https://doi. org/10.4319/lo.1997.42.5_part_2.1223

DALBOSCO, A. L. P., FRANCO, D., BARLETTA, R. C. \& TREVISAN, A. B. 2020. Analysis of currents on the continental shelf off the Santa Catarina Island through measured data. Revista Brasileira de Recursos Hídricos, 25, e7, DOI: http://dx.doi. org/10.1590/2318-0331.252020180175

FALKOWSKI, P. \& KIEFER, D. A. 1985. Chlorophyll- $a$ fluorescence in phytoplankton: relationship to photosynthesis and biomass. Journal of Plankton Research, 7(5), 715-731, DOI: https://doi.org/10.1093/plankt/7.5.715

FENG, L. \& HU, C. 2016. Cloud adjacency effects on top-of-atmosphere radiance and ocean color data products: a statistical assessment. Remote Sensing of Environment, 174, 301313, DOI: https://doi.org/10.1016/j.rse.2015.12.020

FIELD, C. B., BAHRENFIELD, M. J., RANDERSON, J. T. \& FALKOWSKI, P. 1998. Primary production of the biosphere: integrating terrestrial and oceanic components. Science, 281(5374), 237-240, DOI: https://science.sciencemag.org/content/281/5374/237

FOCARDI, S., SPECCHIULLI, A., SPAGNOLI, F., FIESOLETTI, F. \& ROSSI, C. 2009. A combinated approach to investigate the biochemistry and hydrography of a shallow bay in the South Adriatic Sea: The Gulf of Manfredonia (Italy). Environmental Monitoring and Assessment, 153, 209-220, DOI: https:// doi.org/10.1007/s10661-008-0350-2

GARCIA, C. A. E. \& GARCIA, V. M. T. 2008. Variability of chlorophyll- $a$ from ocean color images in the La Plata continental shelf region [online]. Continental Shelf Research, 28(13), 1568-1578. Available at: http://repositorio.furg.br/handle/1/3869 [Accessed: 10 Apr. 2018].

GARCIA C. A. E., GARCIA, V. M. T. \& MCCLAIN, C. R. 2005. Evaluation of SeaWiFS chlorophyll algorithms in the Southwestern Atlantic and Southern Oceans. Remote Sensing of Environment, 95(1), 125-137, DOl: https:doi.org/10.1016/j.rse.2004.12.006

GARCIA, V. M. T., SIGNORINI, S., GARCIA, C. A. E. \& MCCLAIN, C. R. 2006. Empirical and semi-analytical chlorophyll algorithms in the southwestern Atlantic coastal region (25-40 s and 60$45 \mathrm{w})$. International Journal of Remote Sensing, 27(8), 15391562, DOI: https://doi.org/10.1080/01431160500382857

GIANNINI, M. F., GARCIA, A. E., TAVANO, V. \& CIOTTI, A. M. 2013. Effects of low-salinity and high-turbidity waters on empirical ocean colour algorithms: an example for Southwestern Atlantic waters. Continental Shelf Research, 59, 84-96, DOI: https://doi.org/10.1016/j.csr.2013.04.013 
GIESKES, W. W. \& KRAAY, G. W. 1983. Unknown chlorophyll a derivative in the North Sea and the tropical Atlantic ocean revealed by HPLC analysis. Limnology and Oceanography, 28(4), 757-766, DOI: https://doi.org/10.4319/ lo.1983.28.4.0757

GORDON, H. R. 2010. Some reflections on thirty-five years of ocean color remote sensing. In: BARALE, V., GOWER, J. F. R. \& ALBEROTANZA, L. (eds.). Oceanography from space. New York: Springer-Verlag, pp. 289-306, DOI: https://doi. org/10.1007/978-90-481-8681-5_17

GOWER, J. \& KING, S. 2007. An Antarctic ice-related "superbloom" observed with the MERIS satellite imager. Geophysical Research Letters, 34(15), DOI: https://doi. org/10.1029/2007GL029638

GRIMM, A. M. 2009. Variabilidade interanual do clima no Brasil. In: CAVALCANTI, I. F. A., FERREIRA, N. J., SILVA, M. G. A. J. \& DIAS, M. A. F. S. (orgs.). Tempo e clima no Brasil. São Paulo: Oficina de Textos, pp. 353-374.

HENSON, S. A., DUNNE, J. P. \& SARMIENTO, J. L. 2009. Decadal variability in North Atlantic phytoplankton blooms. Journal of Geophysical Research:Oceans, 114(C4), C04013, DOI: https:// doi.org/10.1029/2008JC005139

HENSON, S. A., SARMIENTO, J. L., DUNNE, J. P., BOPP, L., LIMA, I., DONEY, S. C., JOHN, J. \& BEAULIEU, C. 2010. Detection of anthropogenic climate change in satellite records of ocean chlorophyll and productivity. Biogeoscience, 7(2), 621-640, DOI: https://doi.org/10.5194/bg-7-621-2010

HOOKER, S. B., ESAIAS, W. E., FELDMAN, G. C., GREGG, W. W. \& MCCLAIN, C. R. 1992. An overview of SeaWiFS and ocean color. NASA Technical Memorandum 104566. Greenbelt: NASA (National Aeronautics and Space Administration).

HU, C., LEE, Z. \& FRANZ, B. 2012. Chlorophyll alpha-algorithms for oligotrophic oceans: a novel approach based on three-band reflectance difference. Journal of Geophysical Research: Oceans, 117(C1), C01011, DOI: https://doi. org/10.1029/2011JC007395

IOCCG (International Ocean-Colour Coordinating Group). 2000. Remote sensing of ocean colour in Coastal, and other optically-complex, waters. In: SATHYENDRANATH, S. (ed.). Reports number 3 of the International Ocean-Colour Coordenating Group. Dartmouth: IOCCG, pp. 1-140, DOI: http://dx.doi. org/10.25607/OBP-95

IOCCG (International Ocean-Colour Coordinating Group). 2013. In-flight calibration of satellite ocean-colour sensors. In: FROUIN, R. (ed.). Reports number 14 of the International Ocean-Colour Coordinating Group. Darthmouth: IOCCG, pp. 1-106, DOI: http://dx.doi.org/10.25607/OBP-105

IOCCG (International Ocean-Colour Coordinating Group). 2017. Manual for real-time quality control of ocean optics data version 1.1: a guide to quality control and quality assurance of coastal and oceanic optics observations. Silver Spring: IOCCG, DOI: https://doi.org/10.25923/v9p8-ft24

IWASAKI, N., KAJII, M., TANGE, Y., MIYACHI, Y., TANAKA, T., SATO, R. \& INOUE, K. 1992. Status of ADEOS mission sensors. Acta Astronautica, 28, 139-146, DOI: https://doi.org/10.1016/0094$-5765(92) 90019-\mathrm{F}$

JIANG, L. \& WANG, M. 2013. Identification of pixels with stray light and cloud shadow contaminations in the satellite ocean color data processing. Applied Optcis, 52(27), 67576770, DOI: https://doi.org/10.1364/AO.52.006757
KAHRU, M., BROTAS, V., MANZANO-SARABIA, M. \& MITCHELL, B. G. 2010. Are phytoplankton blooms occurring earlier in the Arctic? Global Change Biology, 17(4), 1733-1739, DOI: https://doi.org/10.1111/j.1365-2486.2010.02312.x

KLEMAS, V. 2011. Remote sensing techniques for studying coastal ecosystems: an overview. Journal of Coastal Research, 27(1), 2-17, DOI: https://doi.org/10.2112/JCOASTRES-D-10-00103.1

KÖPPEN, W. \& GEIGER, R. 1954. Klima der Erde (Climate of the earth). Wall Map 1:16 Mill. Gotha: Klett-Perthes.

MAArE (Monitoramento Ambiental da Reserva Biológica Marinha do Arvoredo e Entorno). 2017. Relatório Técnico Final Volume 2: Parâmetros Oceanográficos: Análise de parâmetros ambientais da coluna dágua, plâncton e sedimentos [online]. Florianópolis: MAArE. Available at: http://www.maare.ufsc. br/wp-content/uploads/2018/06/Relatorio_Workshop_ MAArE_2015.pdf [Accessed: 11 Oct. 2019].

MÖLLER, O., PIOLA, A. R., FREITAS, A. C. \& CAMPOS, E. J. D. 2008. The effects of river discharge and seasonal winds on the shelf off southeastern South America. Continental Shelf Research, 28(13), 1607-1624, DOI: https://doi.org/10.1016/j. csr.2008.03.012

MOREL, A. 1974. Optical properties of pure water and pure sea water. In: JERLOV, N. G. \& STEEMAN-NIELSEN, E. (eds.). Optical aspects of oceanography. London: Academic Press.

MOREL, A. \& PRIEUR, L. 1977. Analysis of variations in ocean color. Limnology and Oceanogr, 22(4), 709-722.

O'REILLY, J. E., MARITORENA, S., MITCHELL, B. G., SIEGEL, D. A. M., CARDER, K. L., GARVER, S. A., KAHRU, M. \& MCCLAIN, C. 1998. Ocean color chlorophyll algorithms for SeaWiFS. Journal of Geophysical Research: Oceans, 103(C11), 24937-24953.

PANDOLFO, C., BRAGA, H. J., SILVA JÚNIOR, V. P., MASSIGNAN, A. M., PEREIRA, E. S. \& THOMÉ, V. M. R. 2002. Atlas climatológico digital do Estado de Santa Catarina [online]. Florianópolis: Epagri. Available at: http://www.ciram.epagri.sc.gov.br/index.phpoption $=$ com_contenteview $=$ articleeid=708eltem $\mathrm{id}=483$ [Accessed: 17 Jul 2016].

PAQUETTE, M. 2016. Spatial patterns of benthic foraminifera as a support to the oceanographic characterization of Arvoredo biological marine reserve (South Atlantic, Brazil). Marine Environmental Research, 114, 40-50.

PARK, J. 2010. Variability of seawifs chlorophyll- $a$ in the southwest Atlantic sector of the Southern Ocean: strong topographic effects and weak seasonality. Deep Sea Research Part l: Oceanographic Research Papers, 57(4), 604-620.

PEÑAFLOR, E. L. 2007. Detection of monsoonal phytoplankton blooms in Luzon Strait with MODIS data. Remote Sensing of Environment, 109, 443-450.

PEREIRA, E. S. \& GARCIA, C. A. E. 2018. Evaluation of satellite-derived MODIS chlorophyll algorithms in the northern Antarctic Peninsula. Deep-Sea Research Part Il: Topical Studies in Oceanography, 149, 124-137, DOI: https://doi.org/10.1016/j. dsr2.2017.12.018

PIOLA, A. R., MATANO, R. P., PALMA, E. D., MÖLLER JUNIOR, O. O. \& CAMPOS, E. J. D. 2005. The influence of the Plata River discharge on the western South Atlantic shelf. Geophysical Research Letters, 32(1), L01603, DOI: https://doi. org/10.1029/2004GL021638

PREISENDORFER, R. W. 1976. Hydrologic optics. Honolulu: National Technical Information Service. 
RAST, M. \& BEZY, J. L. 1999. The ESA Medium Resolution Imaging Spectrometer MERIS: a review of the instrument and its mission. International Journal of Remote Sensing, 20(9), 1681-1702.

ROESLER, C., UITZ, J., CLAUSTRE, H., BOSS, E., XING, X., ORGANELLI, E., BRIGGS, N., BRICAUD, A., SCHMECHTING, C., POTEAU, A., D'ORTENZIO, F., RAS, J., DRAPEAU, S., HAËNTJENS, N. \& BARBIDEUX, M. 2017. Recommendations for obtaining unbiased chlorophyll estimates from in situ chlorophyll fluorometers: a global analysis of WET Labs ECO sensors. Limnology and Oceanography: Methods, 15(6), 572-585, DOI: https:// doi.org/10.1002/lom3.10185

RÖRIG, L. R. 2018. Phytoplankton patterns and processes in a tropical-subtropical transition region: Santa Catarina coast, southern Brazil. Plankton Ecology of the Southwestern Atlantic, 1, 269-288.

SACKMANN, B. S., PERRY, M. J. \& ERIKSEN, C. C. 2008. Seaglider observations of variability in daytime fluorescence quenching of chlorophyll- $a$ in Northeastern Pacific coastal waters. Biogeosciences, 5, 2839-2865, DOI: https://doi. org/10.5194/bgd-5-2839-2008

SALOMONSON, V. V., BARNES, W. L., MAYMON, P. W., MONTGOMERY, H. E. \& OSTROW, H. 1989. MODIS: advanced facility instrument for studies of the Earth as a system. IEEE Transactions on Geoscience and Remote Sensing, 27(2), 145153, DOI: https://doi.org/10.1109/36.20292

SCHETTINI, C. A. F., CARVALHO, J. L. B. \& JABOR, P. 1996. Comparative hydrology and suspended matter distribution of four estuaries in Santa Catarina State - Southern Brazil. In: Proceedings of the Workshop on Comparative Studies of Temperate Coast Estuaries. Bahia Blanca: UNS/IADO/NSF/IAI, pp. 29-32.

SEEGERS, B. N., STUMPF, R. P., SCHAEFFER, B. A., LOFTIN, K. A. \& WERDELL, P. J. 2018. Performance metrics for the assessment of satellite data products: an ocean color case study. Optics Express, 26(6), 7404-7422, DOI: https://doi. org/10.1364/OE.26.007404

SHI, W. \& WANG, M. 2007. Observations of a Hurricane Katrina-induced phytoplankton bloom in the Gulf of Mexico. Geophysical Research Letters, 34(11), 121603.
SMITH, C. R. \& BAKER, K. S. 1978. The bio-optical state of ocean waters and remote sensing. Limnology and Oceanography, 23(2), 247-259, DOl: https://doi.org/10.4319/lo.1978.23.2.0247

SONG, H., Jl, R., STOCK, C. \&WANG, Z. 2010. Phenology of phytoplankton blooms in the Nova Scotian shelf Gulf of Marine region: remote sensing and modeling analysis. Journal of Plankton Research, 32(11), 1485-1499.

STERCKX, S., KNAEPS, E. \& RUDDICK, K. 1960. Detection and correction of adjacency effects in hyperspectral airborne data of coastal and inland waters: The use of the near infrared similarity spectrum. International Journal of Remote Sensing, 32(21), 6479-6505.

STRICKLAND, J. D. H. 1960. Measuring the production of marine phytoplankton. Virginia: Fisheries Research Board of Canada.

WANG, M., LIU, X., TAN, L., JIANG, L., SON, S., SHI, W., RAUSCH, K. \& VOSS, K. 2013. Impacts of VIIRS SDR performance on ocean color products. Journal of Geophysical Research: Atmospheres, 118(18), 10-347, DOl: https://doi.org/10.1002/jgrd.50793

WELSCH, C., SWENSON, H., COTA, S. A., DELUCCIA, F., HAAS, J. M., SCHUELER, C., DURHAM, R. M., CLEMENT, J. E. \& ARDANUY, P. E. 2001. "VIIRS (Visible Infrared Imager Radiometer Suite): a next-generation operational environmental sensor for NPOESS. In: IEEE 2001 International Geoscience and Remote Sensing Symposium (IGARSS), 9-13 Jul. 2001, Sydney, NSW, Australia. Sydney: IGARSS, v. 3, pp. 1020-1022, DOI: https:// doi.org/10.1109/IGARSS.2001.976733

WELSCHMEYER, N. A. 1994. Fluorometric analysis of chlorophyll $\mathrm{a}$ in the presence of chlorophyll b and pheopigments. Limnology and Oceanography, 39(8), 1985-1992.

WERDELL, P. J. \& BAILEY, S. W. 2005. An improved bio-optical data set for ocean color algorithm development and satellite data product validation. Remote Sensing of Environment, 98, 122-140.

XING, X., BRIGGS, N., BOSS, E. \& CLAUSTRE, H. 2018. Improved correction for non-photochemical quenching of in situ chlorophyll fluorescence based on a synchronous irradiance profile. Optics Express, 26(19), 24734-24751.

ZHAO, H., TANG, D. \& WANG, Y. 2008. Comparison of phytoplankton blooms triggered by two typhoons with different intensities and translation speeds in the South China Sea. Marine Ecology Progress Series, 365, 57-65. 